\title{
An examination of liability, duty, and disclaimers for the pleasure horse industry in West Virginia and other states
}

Jennifer L. Poling

West Virginia University

Follow this and additional works at: https://researchrepository.wvu.edu/etd

\section{Recommended Citation}

Poling, Jennifer L., "An examination of liability, duty, and disclaimers for the pleasure horse industry in West Virginia and other states" (2008). Graduate Theses, Dissertations, and Problem Reports. 2744. https://researchrepository.wvu.edu/etd/2744

This Dissertation is protected by copyright and/or related rights. It has been brought to you by the The Research Repository @ WVU with permission from the rights-holder(s). You are free to use this Dissertation in any way that is permitted by the copyright and related rights legislation that applies to your use. For other uses you must obtain permission from the rights-holder(s) directly, unless additional rights are indicated by a Creative Commons license in the record and/ or on the work itself. This Dissertation has been accepted for inclusion in WVU Graduate Theses, Dissertations, and Problem Reports collection by an authorized administrator of The Research Repository @ WVU.

For more information, please contact researchrepository@mail.wvu.edu. 


\title{
An Examination of Liability, Duty, and Disclaimers for the Pleasure Horse Industry in West Virginia and Other States
}

\author{
Jennifer L. Poling
}

Dissertation submitted to the Davis College of Agriculture, Forestry and Consumer Sciences at West Virginia University in partial fulfillment of the requirements for the degree of

Doctor of Philisophy

in

Resource Management and Sustainable Development

Dennis K. Smith, Ph.D., Chair

Cyril Logar, D.B.A

Michael T. Olexa, Ph.D.

Doolarie Singh-Knights, Ph.D.

Peter V. Shaeffer, Ph.D.

Division of Resource Management

Morgantown, West Virginia

2008

Keywords: Liability, Negligence, Equine Activity Statute, Duty, Disclaimer 


\title{
ABSTRACT \\ An Examination of Liability, Duty, and Disclaimers for the Pleasure Horse Industry in West Virginia and Other States
}

\author{
Jennifer L. Poling
}

In an effort to protect equine professionals, horse owners, and equestrian participants from liability associated with injury, 45 of 50 states have enacted Equine Activity Statutes. Many of these statutes vary widely with regard to the individuals and types of activities that are afforded protection. Under most state laws there are many requirements for horse owners and equine professionals regarding disclosure of dangerous behaviors in the horse, past medical problems, soundness issues, and other types of risks to potential buyers and handlers. Facility operators and owners are also required to make reasonable efforts to repair dangerous equipment and/or warn visitors of potential hazards on or around the facility grounds. Most people involved in equestrian activities are familiar with waivers and liability release forms; however some are not viewed favorably by the courts. This paper compares and contrasts WV equine laws to similar laws in other states that address liability, duties of horse owners and professionals, and the use of waivers as a means of liability protection. Recommendations for the WV Equine Activity Statute and educational curriculum are made based on the findings of this research and on the input of WV horse owners through a survey. 


\section{Table of Contents}

Chapter I Introduction.......................................................

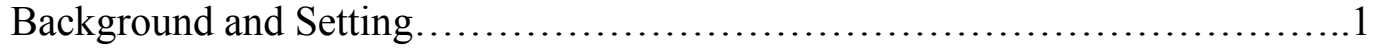

Purpose............................................................... 3

Chapter II Equine Activity Statutes.............................................

Introduction to Equine Liability........................................ 5

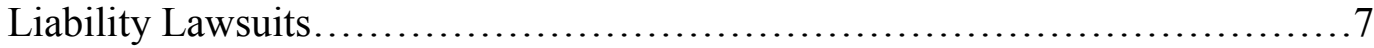

Equine Activity Statutes...............................................11

Activities Covered.................................................. 12

Persons Covered......................................................... 16

Inherent Risks ......................................................... 19

Exceptions to Liability Protection........................................ 21

Signage and Waiver Requirements...................................... 26

Strategies to Avoid Risk...............................................27

Chapter III Duties of the Activity Sponsor and Owner.............................. 31

Health and Safety of the Horse.............................................. 31

Hazardous Conditions and the Landowner................................. 35

Dangerous and Known Propensities......................................42

Matching the Horse and Rider.............................................44

Avoiding Breach of Duty...............................................48

Chapter IV Disclaimers for Liability Protection.................................50

Uses and Form of Disclaimers.........................................50

Content and Wording of Disclaimers.................................... 52

Disclaimers and West Virginia Law......................................57

Chapter V Conclusions and Recommendations................................59

Survey Results.............................................6 60

Appendix A Explanation of Terms.............................................6 63

Appendix B West Virginia Equine Activity Statute................................64

Appendix C WV Horse Owner Survey.......................................67

Appendix D Sample Curriculum..............................................69

References............................................................ 70

Cases..................................................................... 72 


\section{Acknowledgements}

I would like to extend my sincerest thanks to the members of my graduate committee for their constructive comments, suggestions, and guidance throughout this process. Special thanks to Dr. Dennis Smith for his encouragement, advice, and patience during the completion of this work. Thanks also to Hunter Mullens and everyone at Mullens \& McGuire, LLC for the use of their software and guidance in completing the case research. 


\section{Chapter I}

\section{INTRODUCTION}

\section{$\underline{\text { Background and Setting }}$}

Given the steady growth in America's equine industry over the past couple of decades, more and more people are becoming involved with horses in a variety of capacities. Today in the United States thousands of people are training, showing, boarding, riding, racing, breeding, selling, and transporting horses. With all of these activities comes an inherent risk for injury, financial losses, accidents, and property damage. The legal disputes that often result from these activities can cost horse owners, non-horse owners, and equine business professionals a substantial amount of money. Each year in the United States an estimated 102,904 persons are admitted to emergency rooms with nonfatal horse-related injuries according to a study done in 2006 that reviewed records for a three year period between 2001 and 2003 (Thomas, 2006). Most patients were injured while mounted on a horse, usually as a result of falling or being thrown from the horse. Fatal injuries account for approximately 219 deaths per year in the United States based on medical examiner data (Cripps, 2000). Deciding liability for equine related incidents is not always easy. Often the set of circumstances that surrounds an equine incident is complex with many factors.

Equine related activities are associated with an inherent risk due to the potential for injury that accompanies working with horses. In cases where, for example, someone is thrown from a horse and injured, it is possible that no one is liable due to the inherent risk of participating in an equine activity. However this is not always the case. Many times incidents with horses occur due to negligence on the part of the owner, rider, trainer, landowner, or others who may be involved. In these cases the duty falls on the legal system to make a judgment based on the facts and established laws and assign liability to the negligent party. Currently 45 states have in place some version of an equine liability law, usually referred to as an equine activity statute, which helps determine if there has been negligence and where to assign the liability.

A study conducted by the American Horse Council in 2005 revealed that there are currently 9.2 million horses in the United States, which are owned by 2 million citizens. Approximately 4.6 million Americans are involved in the equine industry as horse 
owners, service providers, employees, and volunteers. This industry has a direct economic impact of 39 billion dollars annually in the United States. In terms of value of equine goods and services, the leading states are California, Colorado, Florida, Indiana, and Kentucky (National, 1). With an industry of this size and diversity, it is necessary to establish a comprehensive set of laws and regulations to guide the industry in its continued growth and provide protection for equine owners, land owners, business professionals, and the general public. It is equally essential that these laws be continually evaluated and updated when necessary in order to accommodate the changing demographics of equine activity participants and professionals.

According to an economic impact study done in 2005 there are currently an estimated 56,800 equines involved in racing and non-racing or pleasure activities in West Virginia (Hughes, 2005). The study also reports that the West Virginia equine industry supports nearly 13,000 jobs. Many of these are directly associated with the daily handling of horses. This number does not account for volunteers at equine events, students taking riding lessons, boarders at stables, and many others that also have frequent contact with horses. Though the growth rate of the West Virginia equine industry has not been studied, the group of researchers responsible for the 2005 West Virginia economic impact study surmise that the growth rate could be comparable to the $27 \%$ growth rate estimated for Pennsylvania over the last decade based upon a 2003 study of the Pennsylvania equine industry (Hughes, p. 5, 2005).

The West Virginia equine economic impact study reports an estimated \$287.9 million impact on output in the West Virginia economy, and \$72.2 million of direct payroll and owner-operator profits. The major finding of the study is that "the contribution of all equine related activity to the West Virginia economy is large and important.....and that from all indicators, this contribution of the industry is growing" (Hughes, P. 38, 2005). Though the industry is growing, there is much room for improvement. The study revealed that the majority of horse show activities, 52\%, occurred outside of West Virginia. Several activities such as polo and pony clubs took place entirely (100\%) out of state (Hughes, p. 39, 2005). 


\section{$\underline{\text { Purpose }}$}

In recent years, West Virginia lawmakers have recognized the considerable financial benefit that the equine industry creates for the state and the noticeable increase in West Virginia's equine population. Due to this, the state adopted an equine activity statute in 1994 to help clarify for horse owners, equine activity participants, and the legal system, the standards for applying liability in cases of equine related accidents that result in injury or death (W. Va. Code s 20-4-1). As stated previously, most states have some version of this law; however some are substantially more detailed and comprehensive than others. Some state laws assign a strict liability to equine owners regardless of circumstance, meaning that the horse owner is responsible for all damages caused by their horses in most cases, regardless of negligence. In some states ownership of particular kinds of horses, a stallion for example, is accompanied by strict liability while owning other kinds of horses is not. Some states almost never find a horse owner responsible for damages or injury caused by an escaped horse unless the owner was obviously negligent. In these cases, the individual state laws regarding fencing of livestock would be applied (Clark-Dawe, 2003).

In order to prove negligence, it is first essential to establish that the horse owner or equine activity sponsor had a duty to the injured party. Secondly it must be established that this duty was breached and third, that the breach of duty was the proximate cause of the injury or damage. The majority of the equine activity statutes clearly outline the duties of the equine activity sponsor that must be met in order to receive the full protection afforded by the statute. Breach of duty may result from inadequate care of the horse that leads to the injury of a rider or handler. It may also encompass failure to disclose information about the animal that could result in injury, any hazardous condition of the grounds or facility, failure to properly control the environment, allowing dogs with dangerous propensities to run loose, failure to adequately confine horses, not properly matching the rider and horse based upon skill level, and other forms of negligence. It is the duty of the horse owner to ensure that the horse is properly cared for, and that any problems associated with the horse, whether physical or behavioral, are made known to potential buyers and handlers. The use of disclaimers, either in the form of a posted sign or written waiver, is commonplace among public riding stables and equine businesses. 
Many times the presentation of a signed waiver in a lawsuit will negate the plaintiff's claim. Waivers are generally interpreted very literally by the courts. For this reason it is important that the content and structure of the release be thorough enough to provide adequate protection. Many times a poorly written release is the same as not having a release at all.

The purpose of this paper is to examine and compare the structure and content of West Virginia's equine activity statute with the equine activity statutes in other states and to gain an understanding of the basic knowledge of horse owners regarding the law. Specifically this paper will focus on the duties of the horse owner with regard to the health and safety of the animal, the disclosure of the animal's propensities, the disclosure and control of hazardous conditions, and other duties as they relate to the potential of the animal to injure a rider or handler. Further, the use of disclaimers for the purpose of protecting horse owners and activity sponsors from liability will be examined.

Use of a non-random survey of several individuals involved in the equine industry in West Virginia will provide insight into the knowledge base of horse owners with regard to the law, opinions about the content of the West Virginia Equine Activity Statute, and opinions regarding the enacting of a helmet law for minors in West Virginia. From this information, suggestions will be made regarding the wording of the West Virginia equine activity statute, the need for additional legislation if any, and a suggested educational curriculum for West Virginia horse owners about current laws and risk management strategies. 


\section{Chapter II}

\section{EQUINE ACTIVITY STATUTES}

\section{Introduction to Equine Liability}

Due to the prevalence of equine activities in the United States and the economic benefits generated from these activities, almost every state has enacted some version of an equine liability act in order to protect horse owners, equine activity sponsors, and participants. The presence of these laws helps to limit liability in cases of injury or death to participants due to the inherent risks of equine activities. In most states these laws are referred to as equine activity statutes. As of February 2006, the only states that have not enacted equine activity statutes are Alaska, California, Maryland, Nevada, and New York. The adoption of these statutes is in most cases a fairly recent occurrence. Most states adopted equine statutes in the 1990's in an effort to offer protection with regard to the liability issues that were serving as barriers to equine businesses and the growth of the industry. In terms of the wording contained in these statutes, many states' laws are worded very similar to each other, covering many of the same activities. Some are very thorough and specific while others are more broad and generalized.

The equine activities covered by the statutes typically include shows, rides, competitions, lessons, boarding horses, inspecting horses, horse shoeing, and many times veterinary care (Beethe, 1998). The vast majority of equine activity statutes do not cover any activities associated with horse racing. In states where horse racing is predominant, it is regulated by a separate set of laws. Because the nature of horse racing is more similar to business than to recreation, the injuries sustained by exercise riders, jockeys, and handlers are most often covered by workers' compensation.

In order to fully understand why equine activity statutes are necessary, it is first essential to understand liability. Most of the liability laws related to horses and equine activities in use today stem from case law. Case law is different than common law in that case law is comprised of the rules of law that are announced in court decisions. In other words, case law is an aggregate of reported cases. It is sometimes referred to as "judgemade law". Case law can be viewed as a subset of common law (Clarkson, 1983). Common law comprises principles and rules that relate to the security of persons and 
property, and derives authority from the usages and customs of society (Clarkson, 1983). In most law suits, either a judge or jury examines case law that stems from common law. In cases involving liability, plaintiffs are often looking to recover damages for loss of property value, injuries or death. In most instances, the question posed to the judge or jury is one of negligence.

In order for liability to exist, four elements must be present. These elements include; duty, breach of duty, proximate causation, and damages. A duty exists between the person who caused the accident and the injured party. In equine cases for example, a relationship would exist between a stable owner and a boarder or between a riding instructor and a student. In order to effectively bring a suit against a person, the defendant must have either owed a duty to the injured party to protect them from harm, or at least to not cause them harm. Secondly, the duty must have been breached. This is what caused the accident. For example, a stable owner's knowledge that a horse was known to be dangerous. Third, that the breach of duty must be the cause of the accident. Finally, the injury or some type of damage must have resulted from the accident. This is most often some sort of physical injury to the plaintiff, but can also be property damage resulting from a loose horse or the injury or death of the horse (Clark-Dawe, 2003).

In equine negligence cases, all elements of negligence must be proven in order to collect damages. The exception to this is called strict liability. Strict liability is also called liability without fault and applies to abnormally dangerous activities (Clarkson, 1983). There are a few applications of strict liability within the legal system, aerial pesticide application, blasting, or product liability. In equine cases, strict liability may also apply as equine activities may be viewed as abnormally dangerous in some jurisdictions. For example, some states may hold a horse owner strictly liable for property damage caused by a loose horse. In other states the plaintiff would have to prove that the owner's negligence caused the horse to escape. In states that apply strict liability standards, simply owning a horse is considered an abnormally dangerous activity. West Virginia does not apply a strict liability standard to horse ownership, but uses a percentage- offault system.

Some plaintiffs may argue that owning a certain breed or kind of horse is abnormally dangerous, such as owning a racehorse or an Arabian. These types of horses 
are often thought to be more easily spooked or excited. It might also be argued that owning a stallion is abnormally dangerous because of their aggressive and unpredictable behavior. These arguments are not usually successful as most states require that the plaintiff prove the presence of a dangerous propensity for that particular animal, and that this propensity was known or should have been known by the owner. In Kinley v. Bierly (WL 1027901, 2005) the Superior Court of Pennsylvania held that the fact that a male horse was not castrated alone does not prove a dangerous propensity existed. In Kinley, the plaintiff was injured while feeding her own horse when the defendant's stallion, also boarded at the same barn, bit her as she walked past the stallion's stall. The plaintiff argued that because the defendant's horse was a stallion, the animal had a dangerous propensity for aggressive behavior. The expert witness in this case testified that not all stallions exhibit unpredictable and aggressive tendencies, but the individual personality of the horse plays a large part in determining vicious behavior.

In order to determine whether or not an activity is abnormally dangerous, several factors must be considered. These factors include whether the activity involves a high degree of risk of harm, whether the gravity of the harm is likely to be great, whether the risk can be eliminated by exercising reasonable care, whether or not the activity is a matter of common usage, and the value of the activity to the community (Clarkson, 1983). Equine activities are eligible to be categorized as abnormally dangerous based on individual states' interpretations of these standards.

\section{Liability Lawsuits}

As judges and juries examine civil cases involving liability, they are attempting to ascertain if the people involved were acting in a safe fashion and whether or not something could have been done by the parties to avoid the accident. These questions are often not easy to answer. In most suits where someone was clearly at fault, such as a riding instructor asking a student who has never jumped to jump a five foot fence, the suit is settled prior to trial. Defendants in negligence actions have three basic defenses: superseding or intervening forces, assumption of risk, and contributory or comparative negligence (Clarkson, 1983). 
Superseding or intervening forces are unforeseeable occurrences such as a lightning strike. These forces may break the connection between a wrongful act and the injury. In negligence cases, the defendant often attempts to prove that some intervening act occurred after his or her action, and that act was the proximate cause of the accident. For example, if a student was thrown from her horse while cantering at the direction of a riding instructor she could argue that asking her to canter before she was ready was the proximate cause of her accident. However if at the same time a gust of wind blew a plastic bag into the ring and caused the horse to spook, the riding instructor could argue that the gust of wind was a superseding factor in the accident, and would therefore limit his or her liability. This defense may not always be successful. For example, a situation where an inexperienced rider rents a horse from a local stable to trail ride. Just as the horse begins to trot the rider notices that the strap holding the girth is broken. The rider immediately jumps off before the saddle comes loose, injuring his leg in the process. The stable owner would likely argue that the man was injured because he chose to jump from the horse while the horse was moving, constituting an intervening act. This defense would likely be unsuccessful because the injured plaintiff would argue that he would not have jumped off the saddle if it was in working order. In short, keeping tack in good repair is the responsibility of the stable owner.

In Cole v. Ladbroke Racing (241 N.W. 2d 169, 2000), the plaintiff was injured when the racehorse that he was exercising spooked at a kite that was stuck in a nearby tree, causing the horse to turn sharply to the right, jump a fence, and throw Cole to the ground. The defendant argued that the kite was a superseding force that caused the accident, therefore limiting the defendant's liability. Cole however argued that Ladbroke Racing was negligent in that they failed to properly inspect the premises. Inspection would have revealed the kite. The plaintiff further argued that Ladbroke Racing failed to provide enough outriders to assist the plaintiff. The court found in favor of the defendant. It did so by stating that the unpredictability of a horse's reaction to a kite in a tree, or any other unfamiliar object, was undoubtedly an inherent and foreseeable risk. In addition, the court held that the likelihood of an outrider not being in a position to intercept a runaway horse was also an inherent risk intended to be covered by the broad language of Michigan's Equine Activity Liability Act (Mich. H.B. No. 5006). 
The second defense to negligence is assumption of the risk. This defense argues that a plaintiff who voluntarily enters into a risky situation and is aware of the risks may not recover damages from an accident. The risk can be assumed either by express agreement, such as in signing a waiver, or implied by the plaintiff's knowledge of the risks involved. Most riding stables that allow public riding require participants to sign a liability waiver or release before mounting the horse. These releases usually contain statements describing the risks involved in riding, such as the propensity of horses to spook, buck, kick, bite, and so on, which may result in the injury or death of the participant. A well written release can be very effective in protecting the owner from liability; however a poorly written release may have the same effect as not having one at all. Some states, such as Montana, may not enforce any releases that deal with recreational activities. This is because enforcing the release would be against state policy that will not uphold any contracts that allow people to injure others (Clarke-Dawe, 2003). However in these states it may still be beneficial to have participants sign a waiver to show that they were aware of and knowingly accepted the risks associated with the activity. A signed release will often serve to discourage a party from suing in the event of an injury. In instances where the case goes to trial, the court will begin to review the release in great detail. Generally the court will seek to answer certain questions such as whether the release is understandable, who is covered, what activities are covered, and is the release compliant with state law. Releases are generally viewed with strict scrutiny by the courts (Clarke-Dawe, 2003).

Often a plaintiff will argue that a signed release should be voided because he or she did not read it or was unable to understand the wording. This defense may be ineffective. Simply not reading the release is viewed as the fault of the plaintiff unless it can be proven that the plaintiff was unable to read it due to deception or trickery on the part of the defendant. If a judge or jury reads the release and is able to understand it, the signee should also be able to understand it.

It is common practice for equine businesses to use releases in order to argue an assumption of risk defense. A useful release needs to be clearly written and include all parties that are intended to be covered. It is important to understand the laws regarding releases and equine liability in the particular jurisdictions (Clark-Dawe, 2003). Even 
though New York is one of the few states that does not currently have an equine activity statute, the signing of a release is still beneficial for equestrian activity sponsors. In Eslin v. County of Suffolk (795 N.Y.S. 2d349, 2005), the plaintiff, Eslin, was injured when she fell from a horse. The woman had signed a Horse Rental Agreement and Liability Release Form prior to the accident. The plaintiff fell after she alleges that the horse she was riding suddenly and without warning took off into a gallop causing her foot to be dislodged from the stirrup. The plain wording of the release she had signed warned of the risks associated with horseback riding including that the horse could stop short or change directions or speed at will. The Supreme Court of New York found in favor of the defendant and charges were summarily dismissed.

The third defense to negligence is contributory negligence. All individuals are expected to exercise a reasonable amount of care in protecting themselves from harm. Failure to do so is called contributory negligence. Many states will completely negate a negligence claim if the plaintiff played a role in their own injury. For example if the plaintiff rider was advised not to use spurs on a horse, but used them anyway and was subsequently bucked off and injured, this would likely be viewed as contributory negligence (Clark-Dawe, 2003). In the Utah case of Ellertson v. Dansie (576 P.2d 876, 1978) the plaintiff sued for personal injuries that he sustained while attempting to untangle the defendant's horse from a chain that had been used to tie the horse to a post. The Supreme Court ruled that the plaintiff could not recover for his injuries because it was his knowing and voluntary conduct in going into a "plain-to-be-seen" danger, and that his effort to untangle the horse, while well-intentioned, was the intervening force that caused the horse to rear and strike him.

West Virginia law operates on a comparative negligence system in which a formula is applied in order to determine and assign percentages of liability to each party. Damages are assigned based upon each party's percentage of fault. If someone is determined to be a certain percentage liable for their own injuries, they may not recover the full amount from the defendant. If a West Virginia plaintiff, for example, is found to be $49 \%$ responsible for their own injury they can only recover $51 \%$ of the total damages. However if both parties are $50 \%$ liable for the injury that occurred, no one collects or 
pays damages (Mullens, 2008). A number of states have moved toward narrowing the scope of contributory negligence as a defense (Clarkson, 1983).

\section{Equine Activity Statutes}

As stated previously, a majority of states have enacted some form of equine activity statutes to specifically address liability in equestrian activities. The earliest of these were enacted in 1993, with many of the states passing the statutes simultaneously. Currently Alaska, California, Maryland, Nevada, and New York do not have statutes. New York however is the only state to pass a law requiring that no person under the age of sixteen shall ride a horse without wearing a helmet (New York State, 1999).

Examination of the equine activity statutes in each state reveals certain similarities with regard to their structure and wording. Differences also exist among the laws. Most statutes specifically address equine activities, some group all livestock or domestic animal activities, and others group all recreational activities. Of the 45 states that currently have an equine activity statute, only Connecticut's and Pennsylvania's statutes do not include definition sections. The other statutes provide such a section in which terms such as equine, equine activity, equine activity sponsor, participant, and inherent risks are defined. Some states prelude the liability information with a statement describing why the statute was enacted, for example, to encourage equine business or to protect equine professionals from litigation. Most of the statutes, 30 of 45, share a common format, however some states such as West Virginia, Maine, New Jersey, and Arizona have statutes that differ from the majority in terms of structure and content. West Virginia's equine activity statute contains unique wording, such as the use of the term "horseman" instead of the term "equine professional" as used in other states (W. Va. Code s 20-4-2). West Virginia's statute requires presentation of a statement explaining the liability limitations to a participant prior to engaging in an equine activity. It also requires that every horseman carry public liability insurance. This is quite different from the requirements set forth in the statutes of other states. 


\section{$\underline{\text { Activities Covered }}$}

Most of the statutes provide protection from liability for certain equine activities, but not all equine activities are covered. States such as Alabama, Florida, New Hampshire, South Carolina, and others share a common format that includes a thorough and concise definition of "equine activity". For most states, equine activities are defined as equine shows, fairs, competitions, performances, or parades that involve any or all breeds. This includes a variety of disciplines such as jumping, barrel racing, cutting, dressage, and other competitive events. Also included in the list of equine activities for many states is equine training or teaching, boarding, riding, inspecting, rides, trips, hunts, placing or replacing shoes, or administering medical treatment. Arizona and Connecticut statutes do not provide a list of equine activities which are covered. Many of the states that currently have an equine activity statute specifically address horse racing as a separate entity not covered by the same liability protection afforded to other types of equine activities.

Though a state might include in its statute a list of equine activities covered, this is open to interpretation by the courts and may provide an opportunity for litigation depending upon the individual case. The equine activity statute in Illinois (Illinois State Senate, 1995) for example, is constructed much like the majority of states, with a very concise and comprehensive list of what equine activities are to be covered. The definitions set forth in the Illinois statute state in section (10a), P. 111, Sen. Bill 240, that "engages in an equine activity means riding, training, assisting in medical treatment of, driving, or being a passenger upon an equine, whether mounted or unmounted, or assisting a participant." Section (10c) P. 111, Sen. Bill 240, provides a list of equine activities which are intended to be covered, and includes most shows, competition, fairs, and other riding and training disciplines. In section (10c), item number (4)P.114, Sen. $\underline{\text { Bill } 240}$ also lists as an equine activity the "riding, inspecting, or evaluating of an equine belonging to another, whether or not the owner has received some monetary consideration or other thing of value for the use of the equine or is permitting a prospective purchaser of the equine to ride, inspect, or evaluate the equine".

The intent of the authors of the Illinois statute with regard to equine activities was questioned in Carl v. Resnick (714 N.E. 2d 1, 1999). Plaintiff Carl was riding her horse 
on a public trail when she came upon defendant Resnick riding her horse with a companion, Paddock, who was also riding a horse owned by Resnick. As the three were talking, the horse Paddock was riding turned and kicked Carl and her horse. One hoof struck the Plaintiff's leg, injuring her. The trial court found in favor of the defendant in summary judgment, barring the plaintiff's complaint based on the Illinois Equine Activity Statute. On appeal, however, the decision of the trial court was reversed. The appellate court stated that in her motion the defendant argued that the plaintiff was engaged in an equine activity as defined by section (10a) P. 111, Sen. Bill 240. Though the court admitted that plaintiff Carl was "riding... an equine" at the time of the accident, the court found that section (10a) was intended to be read in conjunction with section (10c) P. 111, $\underline{\text { Sen. Bill } 240}$ in that only those engaged in an equine activity that falls into one of the discipline categories listed would be covered. In her brief on appeal, the defendant discussed only one of the categories enumerated in (10c) "riding, inspecting, or evaluating an equine belonging to another". The court failed to see how the activity of the defendant fell within these parameters, and that even though the defendant was riding a horse belonging to another, the plaintiff was riding her own horse. This case was remanded to trial on the issues of liability and damages.

West Virginia's statute provides protection for most equine activities, but does not specifically address veterinary treatment, farrier services, transportation, or breeding activities (West Virginia State Senate, 1997). Due to the nature and behavior of horses during times of breeding, there is a higher likelihood of injury to handlers and to horses. Stallions often become aggressive when approaching mares in estrus and may kick, bite, or strike at handlers. Mares also become more dangerous and may kick out at the stallion, injuring a handler in the process. Currently there are only seven states, Iowa (Iowa Code Ch. 673), Virginia (Title 3.1, Ch. 27.5), Ohio (․․B. No 564), Pennsylvania (4 P.S. 601606), Maine (Title7, Ch 743), North Carolina (h. 99E), and Michigan (․․ B. No 5006), which address horse breeding activities as one of the equine activities afforded liability protection. North Carolina's statute covers any activity involving an equine (Ch. $99 \mathrm{E}$,

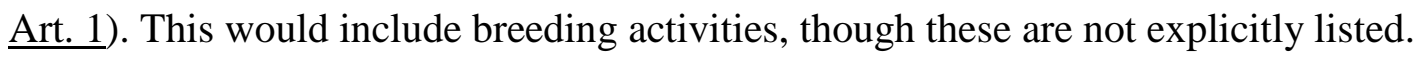
Horse racing on flat tracks is generally considered an abnormally dangerous activity. Race horses typically are very fit and can be difficult to handle. Because of a 
variety of factors including genetics and the environment at a racetrack, race horses are usually very easily excited or spooked. Injuries to exercise riders, jockeys, trainers, grooms, and handlers are very common in the horse racing industry. Some horses continue to participate in racing while still injured or while recovering from an injury. Though it is somewhat less common than it was several years ago, many horses are still raced with injuries such as bowed tendons or strained ligaments. Horses at a racetrack are started very young, some even before they turn two years old. At this age tendons, ligaments, and bones are not fully developed but are subjected to a very strenuous training regimen. This increases the likelihood that the horse may stumble or go down in training with an exercise rider or in a race with a jockey aboard. In the United States each year, there are approximately 606 injuries that require medical attention for every 1000 jockeys. Almost a quarter of these injuries are sustained to the head and neck (Waller, 2000). This is one of the reasons that most states do not afford liability protection for the horse racing industry. Horse racing is an activity in which strict liability is often applied. Seven states, North Carolina (h.99E, Art.1), Utah (Title 78, Ch 27b), Maine (Title 7, Ch 743), South Dakota(Title 42, Ch. 42-11), New Mexico(N.M. Ann. S42-13-5), Oklahoma(Title 76, Ch. 326), and Kansas(Ch. 290, H.B. 2222), include horse racing as an equine activity covered by statute. Twenty two states list horse racing as an activity not covered by statute. These include states such as Florida, Kentucky, West Virginia, and Delaware, where horse racing provides a large percentage of the total economic impact of the equine industry. Eighteen states do not mention horse racing as an equine activity.

Transporting horses by trailer involves a higher degree of risk than most other types of equine activities. Some horses are fearful of trailers and of being transported. This can cause a relatively safe animal to become defensive and dangerous, resulting in injury to the animal and handler. During times of loading and unloading horses, the likelihood of injury increases substantially. There are many methods used to load reluctant horses onto trailers, one of which is for two handlers to lock arms behind the horse and push it into the trailer. Though widely used, this method is very dangerous as it can result in the handler being kicked or stepped on. It is important to note that only five states, New Jersey (NJ ST 5:15), Maine (Title 7, Ch 743), Iowa (Iowa Code Ch. 673), 
Minnesota(h. 604A) , and Ohio(․ㅡ.B. No 564), list "trailering, loading, unloading, or transporting equine" as one of the equine activities for which liability protection is provided. North Carolina (h. 99E) and Pennsylvania (소 ST 4 P.S. $)$ are the only two states which specifically address a collision or accident involving a motor vehicle as an activity that is not covered by the statute. West Virginia's statute does not specifically address the transporting of horses.

There are several states, such as Oklahoma (Title 76, Ch. 326), Iowa (Iowa Code Ch. 673), Kentucky (KRS 247.401), and Kansas (Ch. 290, H.B. 2222), which collectively group all livestock or domestic animal activities and do not have a statute unique to equine activities. However, these statutes do list equine among the livestock or domestic animals covered, and define "livestock activity" using the same terms as other states with equine activity statutes, but simply replace the word "equine" with the word "livestock" (Title 76, Ch. 50.3), Wyoming (Wy. Stat. s 1-1-121) and Wisconsin (Wis. Stat. s 895) both have statutes that group all recreational activities. Wisconsin's statute defines recreational activity as "any activity undertaken for the purpose of exercise, relaxation, or pleasure" (Wis. Stat. s 895.525), and provides a list of recreational activities which includes horseback riding and animal training. This statute covers all participants in a recreational activity on land or facilities provided by a person who offers recreational activities to the general public. The statute states that by participating in the recreational activity, the participant assumes the risk involved and the provisions of comparative negligence shall apply (Wis. Stat. s 895.525). In Kangas v. Perry, (NW 4d 429,2000) plaintiff Kangas was injured while being a passenger in a horse sled drawn by horses owned by Perry, who was not a professional. Kangas fell from the sled when the horses unexpectedly lurched forward. The plaintiff argued that the recreational activity statute of Wisconsin could not be applied to the case because it was intended to apply to equine professionals only. The Wisconsin Court of Appeals held that under the plain wording of the statute, it applied to all participants in equine activities whether they were professionals or not.

Wyoming's Recreation Safety Act (Wy. Stat. s 1-1-121) is somewhat different in that it provides a full list of equine activities under the definition provided for "sport or recreational opportunity". This statute states that "any person who takes part in any sport 
or recreational opportunity assumes the inherent risk of injury and all legal responsibility for damage, injury, or death to himself or other persons or property that results from the inherent risks in that sport or recreational opportunity" (Wy. Stat. s 1-1-123). Further, the act states that the provider of the recreational activity is not required to eliminate or control the inherent risks associated with that activity.

\section{$\underline{\text { Persons Covered }}$}

Most of the equine activity statutes provide liability protection for equine professionals and activity sponsors, providing that their negligence did not contribute to the accident. West Virginia's statute provides liability protection for "horsemen" and “operators of a horseman's business" (WV Stat. s 20-4-2). This is defined as "any individual, sole proprietorship, partnership, association, public or private corporation, in the United States or any federal agency, this state or any political subdivision of this state, and any other legal entity which engages, with or without compensation, in organizing, promoting, presenting, or providing equestrian activities or in providing facilities for equestrian activities" (WV Stat. s 20-4-2). According to the West Virginia statute, participants may not recover damages from horsemen for injuries or death resulting from the inherent risks of equestrian activities. "Participant" is defined as "any person using the services or facilities of a horseman so as to be directly involved in an equestrian activity" (WV Stat. s 20-4-2). It can be inferred from the statute that spectators would not be covered under the current provisions because being a spectator would not constitute direct involvement in the equestrian activity.

Though most states provide liability protection similar to the type afforded to horsemen in West Virginia, other states do not use the term "horsemen". Wyoming's Recreation Safety Act provides protection for "providers" meaning "any person or governmental entity which for profit or otherwise, offers or conducts a sport or recreational opportunity" (Wy. Stat. s 1-1-123).

Minnesota(Ch. 604A), Iowa(Iowa Code Ch. 673), Oklahoma(Title 76, Ch. 326), and Kansas (Ch. 290, H.B. 2222) group all livestock or domestic animal activities and provide protection for "livestock activity sponsors" or "domestic animal activity sponsors". In Minnesota, a livestock activity sponsor is only covered if the activity is not 
performed for profit $(\underline{\mathrm{Ch} .604 \mathrm{~A})}$. Iowa's statute does not provide protection for activity sponsors in cases where injury or death occurs to a spectator who is in a place where a reasonable person who is alert to inherent risks of domestic animal activities would not expect a domesticated animal activity to occur(Iowa Code Ch. 673.2). Oklahoma(Title $\underline{76, \text { Sect. 50.2) }}$ and Kansas(Ch. 290, H.B. 2222, Sect. 1) statutes state that "engages in a livestock activity" does not include being a spectator at a livestock activity, except in cases where the spectator places himself or herself in immediate proximity to a livestock activity.

Arizona's equine activity statute provides limited liability for equine owners and owners of equine facilities, meaning "an owner, lessor or agent of any riding stable, rodeo ground, training or boarding stable or other private property that is used by a rider or handler of an equine." (A. R. S. s 12-553). This statute does not specifically address spectators or equine activity sponsors that are not the owners of the equine or the owners of the facility. Therefore, this statute would not provide liability protection for groups such as riding clubs that sponsor activities, shows, or rides using a private or public facility. It would only protect the facility owner and horse owners.

The state of New Jersey uses the term 'operator', and defines this as "a person or entity who owns, manages, controls or directs the operation of an area where individuals engage in equine animal activities whether or not compensation is paid. 'Operator' shall also include an agency of this State, political subdivisions thereof or instrumentality of said entities, or any individual or entity acting on behalf of an operator for all or part of such activities" (NJ ST 5:15-2). The statutes in New Jersey and Maine(Title 7, Ch 743) state that participants and spectators assume the inherent risks of equine activities created by equine animals, weather conditions, trail conditions, riding rings, and all other inherent risks. This is similar to the majority of other states with regard to participants; however in most other states spectators are not given the same consideration as participants.

In Amburgey v. Sauder (238 Mich. App. 228, 605 NW 2d84) the Michigan Court of Appeals upheld the trial court's decision to grant summary judgment to the defendant in a case where the plaintiff, Amburgey, was injured when a horse bit her as she passed his stall during a visit to the defendant's stable. Amburgey visited the stable in order to 
watch a friend's riding lesson. Amburgey argued that the provisions of immunity provided by the Michigan Equine Activity Statute did not apply in this case because she was merely a spectator, not a participant. During the trial it was discovered that while she was waiting on the lesson to begin, Amburgey was offered a tour of the stable. It was during this tour that the accident occurred. The plain language included in the Michigan statute says that "engages in an equine activity includes visiting, touring, or utilizing an equine facility as part of an organized event or activity including the breeding of equines, or assisting a participant or show management" (Mich. H. B. No 5006). The court barred the plaintiff's claim, finding that at the time of her accident she was involved in an equine activity as defined by the statute.

The majority of equine activity statutes provide liability protection equally for equine professionals and for equine activity sponsors. Some states, however, do not provide protection for professionals, employees, or those working for profit. Arkansas (Ark. Stat. Ann. s 16-120-201) and Vermont (12 V.S.A. 1039) provide liability protection for equine activity sponsors only. These states do not address equine professionals. Both of these statutes do include activity sponsors that operate for profit. New Mexico's equine activity statute addresses injuries or death to riders only, not all participants in an equine activity (N.M. Stat. Ann. S 42-13-2).

Many of the statutes do not specifically list veterinarians and farriers as equine professionals, but define "equine professional" as a person engaged for compensation in instructing participants, renting horses to participants to ride, or renting tack to participants. In these states, if a farrier or veterinarian was injured during the administering of care to the equine, or if the handler was injured while assisting the veterinarian or farrier, the statute may not apply. Some states hold professionals such as veterinarians and farriers to a higher standard of care. West Virginia's statute does not address veterinary or farrier services as activities which are afforded liability protection (WV Stat. s 20-4-2). Of the 45 equine activity statutes, there are 27 which specifically list veterinary care or the assistance of medical treatment of an equine as one of the equine activities covered by the statutes. Oklahoma's statute does not apply to employees of the activity sponsor or livestock professional in the performance of their duties who are covered by the provisions of workers' compensation (Title 76, Sect. 50.2). 


\section{$\underline{\text { Inherent Risks }}$}

Often the first question to be answered in an equine related injury case is whether the damages were caused from a dangerous propensity of the particular equine, or if the cause was related to the inherent risks associated with working with horses. Most of the equine activity statutes provide liability protection for injuries or death occurring as a result of the associated inherent risks. Generally these risks are defined in the statutes as those dangers or conditions which are an integral part of livestock activities. Connecticut is the only state that does not include in its statute an explanation of what are to be considered inherent risks (Conn. Gen. Stat. s 52-577p). The majority of the other states share a very similar list of what are to be considered inherent risks. Generally this includes: the propensity of the equine to behave in ways that may result in injury to persons on or around them; the unpredictability of an equine's reaction to such things as sounds, sudden movement, and unfamiliar objects; certain hazards such as surface and subsurface conditions unknown to the activity sponsor; collisions with other livestock or objects, and the potential of tack to become dislodged through no fault of the activity sponsor. A minority of states also list as one of the inherent risks the potential of a participant to act in a negligent manner that may contribute to injury to the participant and others, such as failing to maintain control of the equine or not acting within his/her ability.

This leaves room for argument regarding whether the animal had a known propensity for dangerous behavior or whether the accident was due to the inherent risks of equine activity. In cases where someone was thrown from a horse and injured, the defense would likely argue that the injury was a direct result of the natural flight response of the horse to a sudden stimulus through no fault of the activity sponsor or professional. The plaintiff's attorney could argue that the animal was known to have a propensity to buck that was not revealed to the participant prior to the accident. In order to be effective, the prosecution would have to prove that the animal's propensity for dangerous behavior was known to the owner or should have been known, and that this behavior was the cause of the injury. This argument may not be effective for example in a case where a horse was known to have a propensity to kick, but the participant was injured due to the horse bucking them off. It would be difficult to prove that the known propensity of the horse to 
kick was the proximate cause of the accident. Also, if the owner meets his or her legal obligation to warn the participant of the horse's dangerous propensity, and the participant chooses to ride the horse despite the warning, the owner cannot be held liable for injuries caused by the dangerous behavior.

There are instances when the horse communicates its dangerous propensity to the rider prior to an accident. If the rider chooses to stay mounted without regard to the animal's behavior then the rider has assumed the risks associated with riding that particular equine. In order for a plaintiff to successfully use the dangerous propensity argument to assign liability, the plaintiff must first prove that the behavior was unusual. A horse that spooked due to someone waving a plastic bag at it would not be considered to have a dangerous propensity for spooking because that behavior would be considered normal for any horse in a similar situation. Secondly, the plaintiff must prove that the owner or activity sponsor knew or should have known about the animal's dangerous behavior. This does not require strict proof that the owner had direct knowledge of the behavior because that would encourage owners to purposely avoid direct knowledge of their horse's actions in order to escape liability. The standard of proof used in cases of dangerous propensities is whether or not a reasonable person in the owner's position would have known about the dangerous behavior. For example, if the horse was known around the stable to have a propensity to kick, and this was something that was talked about among stable workers, farriers, grooms, etc. then the plaintiff would argue that the owner should have known about the propensity, even if the owner had no direct knowledge of the behavior (Dawson, 2006).

In Jividen v. Law v. Kovacs (Civil Action No 90-C-162, 90-C-390) the West Virginia Supreme Court of Appeals found in favor of the defendants Law and Kovacs in a case where a colt, owned by Kovacs and boarded at Law's barn, kicked and caused the death of Delvious Jividen. Jividen visited the home of Law for the purpose of loading three steers that he had purchased. The steers were corralled with a 6 month old colt, Keno, who was recovering from a leg injury. As the Laws and Mr. Jividen were preparing to load the steers, Mrs. Law put a halter on the colt and was holding him. During this process Keno became agitated and began backing up and pulling on the rope. Mr. Law walked over and pulled on the rope to calm Keno, at which point Mr. Jividen 
took the rope to hold Keno while the Laws loaded the steers. At some point during this time Keno kicked Mr. Jividen, who sustained chest and head injuries and died a few days later. The estate of Mr. Jividen filed a wrongful death suit claiming that the colt had dangerous and vicious tendencies which were known to the Laws and to Kovacs, and that the Laws should have removed Keno from the corral. The Appellant submitted statements of Mr. and Mrs. Law stating that the colt was "a bit frisky". They also submitted a statement from a relative of Mr. Jividen who testified that Mr. Law told her that Keno was "a rambunctious, wild colt", and that Keno preferred to "run and play" as opposed to being penned(Civil Action No 90-C-162, p. 3). The court found that there was not sufficient evidence that Keno ever displayed any vicious tendency or predisposition toward violent behavior. Further the court ruled that the Laws exercised the proper amount of care in handling the colt, stating that the "amount of control required is that which would be exercised by a reasonable person based upon the total situation at the time, including the past behavior of the animal and injuries that could have been reasonably foreseen" (Civil Action No 90-C-390, p. 8).

Some may argue that horses of a certain breed are more dangerous than others, and as such have dangerous propensities because of genetic factors. As an example, Arabians and Thoroughbreds tend to spook easily so an accident involving one of these breeds can be attributed to their propensity to misbehave. Most courts have not upheld dangerous propensity cases in which a horse of a certain breed is considered dangerous. The propensity must be shown by the specific horse in question in order to be a successful claim (Clark-Dawe, 2003). Pennsylvania is the most recent state to adopt its equine activity statute (PS St. 4 PS 601-606). It is the only statute that specifically states that evidence of viciousness of the equine is not necessary in order for the possessor of the equine to be subject to liability for harm.

\section{Exceptions to Liability Protection}

Many equine professionals, activity sponsors, and participants are protected from liability as provided by the wording in the individual equine activity statutes for 45 states. In most cases this liability protection is effective in instances of injury or death due to the inherent risk associated with being around horses. This protection in some instances 
extends to veterinarians, farriers, spectators, landowners, riding clubs, and others who may be involved in the activity. However, in every state there are times when liability protection is voided due to certain acts or omissions by the parties. Equine activity sponsors, for the most part, have a duty to participants to make reasonable efforts to ensure that the activity is safe to the best of their ability, and to make an effort to determine the competence of the participant in completing the activity. In general, activity participants have a duty to accurately and honestly convey their level of experience and ability in terms of participating in the equine activity and maintaining control of their mount. Most statutes include a section outlining the exceptions to liability protection. Of the 45 states that have equine activity statutes, only three, Wyoming $(\underline{W y}$.

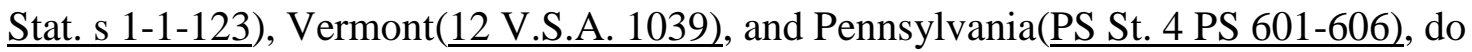
not include a specific list of conditions which must be met to attain full protection from liability.

West Virginia's statute falls within the majority, containing a precise list of criteria under which a "horseman" may be liable. These are fairly consistent with the criteria listed in other states' statutes. In West Virginia and most other states, a horseman, or equine activity sponsor, has certain duties to activity participants that include

(1) making reasonable and prudent efforts to determine the ability of the participant to engage in the activity and the ability of the horse to behave in a safe manner, (2) making known to participants any dangerous traits or characteristics of the particular horse which the horseman knows or should know, (3) making dangerous conditions on the land or around the facility known to the participants by advising them in writing or through the use of posted warning signs, and (4) making reasonable efforts to inspect equipment and tack to assure that it is in proper working order and safe for use (WV Code s 20-4-3).

The West Virginia statute also requires that each participant be presented with a statement which clearly and concisely explains the liability limitations and restrictions to be inspected and signed by the participant (WV Code s 20-4-3). This is somewhat unique to a few states such as West Virginia and Oklahoma, as most other states may have signage requirements, but do not specifically require the presentation and signing of a waiver. Additionally, the West Virginia statute expressly states that every horseman is required to carry public liability insurance in limits of no less than one hundred thousand 
dollars per person, three hundred thousand dollars per occurrence, and ten thousand dollars for property damage. This is the only state statute with this requirement.

Failure to follow these conditions and duties, in instances where the violation of duty is causally related to the injury or damage, constitutes negligence whereby the activity sponsor may be held liable. Under the West Virginia statute, the participant also has certain duties which include having the sole and individual responsibility for knowing the range of his or her abilities and to act within the limits of those abilities. Acting outside one's abilities or misrepresenting skill level can bar a plaintiff from collecting damages. This was apparent in a 2007 case in which a plaintiff, Rutecki sued CSX Hotels, Inc.(S.D. WL 192514) for injuries she sustained while participating in a trail ride at the Greenbriar Resort. Mrs. Rutecki signed a release prior to the trail ride, but neglected to fill out the portion detailing her experience with horse. The guide chose a horse for Rutecki that had been used for private and group trail rides for over ten years without incident. While on the ride the guide's horse was startled, causing him to jump from his mount, which startled the plaintiff's horse causing her to fall and injure her back. Rutecki sued the Greenbriar for negligence. The West Virginia District Court ruled in favor of summary judgment for the defendant stating that "there is not dispute that a horse is a powerful and sometimes unpredictable animal" .(S.D. WL 192514, P.11Sec.IV). For these reasons the court found that the purpose of the West Virginia statute was to provide protection for equine businesses in instances where injuries were sustained that resulted from the inherent risks associated with equine activities. In this case the plaintiff failed to show evidence of gross negligence. It was shown that by signing the release, she was aware of the risks involved and voluntarily neglected to share her lack of riding experience with the guide.

The majority of states require similar duties of the activity sponsor and participant, with some minor differences. Variation occurs most often in terms of the requirements for determining the ability of the participant to engage in the activity. Most states, such as Illinois (Illinois Public Act 111), Oklahoma(OK Ch. 326, HB No. 1152), and Louisiana (La. R.S. 9:2795.1), require that the equine activity sponsor make reasonable efforts to determine the participant's ability based on that participant's representation of their skill level. In other words the participant is responsible for 
accurately portraying their own skill level. An act or omission by the participant, in terms or their ability or experience, which leads to his or her injury, constitutes negligence on the part of the participant. In these cases the participant contributed at least partially to their own injury, therefore making a claim against the sponsor more difficult. Only the Michigan statute states that an equine activity sponsor "shall not rely upon a participant's representations of his or her ability unless these representations are supported by reasonably sufficient detail" (MI HB 5006, Sect. 5). Some states, such as West Virginia (WV Code s 20-4-3) and North Carolina (NC Ch. 99E, Art.1), require only that the sponsor make an effort to determine the ability of the participant, but do not specify whether or not the activity sponsor is to rely on the participant's representations or on other means of assessing ability.

The New Jersey equine activity statute is the only statute that specifically addresses alcohol and drug use by participants, stating that "a participant or spectator shall not engage in, attempt to engage in, or interfere with, an equine animal activity if he is knowingly under the influence of any alcoholic beverage or under the influence of any prescription, legend drug, or controlled dangerous substance” (NJ ST 5:15.4).

Providing faulty tack is a common cause of injury, especially among commercial riding stables or trail riding outfits. This is the most widely included statement in the exceptions to liability protection sections of all the statutes. Almost every statute, with the exception of Vermont, Wyoming, and Pennsylvania, makes reference to the duties of the activity sponsor with regard to providing equipment and tack. In the vast majority of statutes, knowingly providing equipment or tack to the extent that it causes or contributes to the injury is a cause of exception to liability protection. Some states, such as Oklahoma, however do not require direct knowledge of faulty tack in order for the sponsor to be held liable. In these states, providing tack or equipment that breaks or is faulty is enough to warrant a claim against the sponsor, whether or not the sponsor knew or should have known about the condition of the tack. The West Virginia statute is very similar to the majority in its statement regarding tack and equipment, stating that the horseman or sponsor must "make reasonable and prudent efforts to inspect such equipment or tack to assure that it is in proper working condition and safe for use in the equestrian activity" (WV Code s 20-4-3). It may be difficult to prove that the tack was 
defective and that this defect was known to the activity provider and this was the proximate cause of the injury. In Terrill v. Stacy (WL 473799, 2006) the Michigan Court of Appeals granted summary judgment to the defendant when the plaintiff was injured during a horseback ride when the horse's bit broke, and she could not regain control of the horse. The court found no proof that the bit was previously defective or that this defect was known to the defendant. Further, the plaintiff signed a waiver releasing the defendant from "any and all injury" that may occur during the ride.

Similar to the duties required of a horse seller, the equine activity sponsor is responsible for conveying any information known about the propensity of the horse to act in a dangerous fashion. This is known as the "duty to warn", and encompasses any dangerous or vicious behavior regarding the horse that the sponsor knew or should have known. In West Virginia, the horseman has a duty to "make known to any participant any dangerous traits or characteristics or any physical impairments or conditions related to a particular horse which is involved in the equestrian activity of which the horseman knows or through the exercise of due diligence could know" (WV Code s 20-4-3). Most other states that specifically list exceptions to liability protection in their statutes include a general statement that any willful act or omission by the sponsor that constitutes negligent disregard for the participant's safety is grounds for liability. It could be inferred that not disclosing a dangerous propensity of the horse would be considered an act or omission showing negligent disregard. In Konan V. George (WL 1020734, 2002) the plaintiff Konan was test riding a horse owned by defendant George by riding the horse in a clockwise direction on Suffolk Downs racetrack. The horse, which had never liked being ridden in that direction, bucked Konan off, injuring him. The defendants sought summary judgment based on the protection of the Massachusetts equine liability statute. The court denied motion for summary judgment due to the factual issue of whether or not Konan was warned about the horse's dislike for travelling in the wrong direction prior to his accident. 


\section{$\underline{\text { Signage and Waiver Requirements }}$}

Posting signs or having equestrian activity participants sign waivers are both commonly used to help protect the activity sponsor from liability. Waivers and signage will not excuse negligence on the part of the sponsor or participant, but they can help to make clear to participants the risks involved with equine activities. A signed waiver may also be used to show that the person was aware of and assumed the risk of injury or death associated with the activity. It is usually recommended to equine professionals that they utilize a well-constructed waiver and post signs containing the wording found in the statute in readily apparent locations around the stable or facility. Beyond this, most states make mention of signs and waivers in their equine activity statutes. Only nine of 45 states, Washington (Wash. S 4.24.530), North Dakota (ND Code s 53-10-01), Idaho (ID Code s 6-1801), Connecticut (Conn. Gen. Stat. s 52-577p), New Hampshire (NH Stat. s 508:19), Hawaii (HRS s 663B-1), Montana (Mont. Code s 27-1-725), Wisconsin (Wis. Stat. s 895-525), and Wyoming (Wyo. Stat. s 1-1-121), do not specifically address the use of posted signs and releases.

The large majority of the states, 27 of 45, contain similar statements with regard to signs and waivers. These states require that equine professionals and activity sponsors post visible signs in areas where they are likely to be seen by activity participants. Many of these states provide details such as requiring black lettering of at least one inch in height, or signs that must be two feet by three feet so as to make them more clearly visible. The signs must contain the specific wording found in the individual statute with regard to liability limitations and inherent risks associated with equine activities. These states also require that if a release is used, it must contain the same language as found in the posted signs. In these states, not posting the required signs may bar the sponsor from protection of the statute; however the use of a release is optional.

There are only two states, Florida (Fla. Stat. s 773.01) and Illinois (IL Public Act 111 SB 240), which require the use of posted signs and a signed release by the participants. The release used must clearly outline the risks associated with equestrian activities and must use the language contained in the equine activity statute that relates to liability. Florida's statute is unique in that a release may be used in lieu of a posted sign so long as it contains the proper language; however a posted sign may not be used in lieu 
of the release. In the 2004 case of McGraw v. R and R Investments (877 s0.2d 886, 2004) the Florida Court of Appeals overturned the decision of the lower court for summary judgment in favor of the defendant. In this case, the plaintiff McGraw was injured when thrown by a horse while working as a trainer for the defendant, $\mathrm{R}$ and $\mathrm{R}$ Investments. The Court of Appeals disagreed with the findings of the lower court, stating that "failure to post the signs required by the statute deprives the equine professional of the benefits of the statute" (877 s0.2d 886, 2004, p.1). Therefore the case was remanded to trial.

West Virginia(WV Code s 20-4), Oregon (ORS s 30.687), Arizona (ARS s 12553), Virginia (VA s 3.1-796.130), Ohio (OH HB No. 564), and Oklahoma (OK HB No.1152), have statutes that require presentation of a waiver to participants for their signature, but make no mention of posted signage requirements. The statutes in these states convey that one of the conditions that must be met for protection under the law is that the sponsor must "prepare and present to each participant or prospective participant, for his or her inspection and signature, a statement which clearly and concisely explains the liability limitations, restrictions and responsibilities set forth in this article" (WV Code s 20-4-3). In the 2003 Arizona case of Lindsay v. Cave Creek Outfitters(88 P.3d 557, 2003), the signing of a release by the plaintiff barred her claim for damages when her horse bucked violently and threw her after being stuck by cactus spines while on a desert trail ride. Though Lindsay argued that the guide did not stay on established trails and that she did not read the release before signing it, the court granted summary judgment for the defendant. Maine is the only state that appears to give equal weight to either a posted sign or a signed waiver, stating that "notice of the inherent risks of equine activity may be satisfied either by a statement signed by the person injured or by a sign or signs prominently displayed at the place where the activity initiated"(ME Stat. s 41017A).

\section{Strategies to Avoid Risk}

Most horse owners are aware that working with and around horses can be dangerous. Most people who have spent years around horses have sustained some type of horse-related injury at some point and may take for granted that others are aware of the risks associated with equine activities. It is this assumption that can often lead to injury, 
litigation, and financial burdens for the activity sponsor, equine professional, and participant. All horse owners should be aware of the exact wording in their individual state statutes. As has been shown, there is much variation between the states, and what is not required of the horse owner in one state may bar liability protection for a horse owner in another state. Some of the major differences between the equine activity statutes are summarized in Table 1 on pages 29 and 30.

In order to be prepared to enter an equine business, promote, sponsor, or host events, or provide facilities for equestrian events, individuals should first fully understand what triggers liability and how to avoid negligence. Sound safety management plans and training procedures for employees should be standard practice for equine businesses. Also, it is necessary to attain the aid of counsel to construct sound and thorough releases, contracts, and posted signs. Landowners should make a reasonable and prudent effort to inspect the premises and make known to participants any dangerous conditions that exist on the property. It is clearly stated in the West Virginia statute that it is the responsibility of the activity sponsor to ascertain the skill level of the participants and to clearly and honestly portray any physical or behavioral problems with the horse prior to the activity. Horsemen or operators of a horseman's business in West Virginia should also have adequate insurance in the amounts specified in the statute. 
Table 1

Equine Activity Statute Summary

\begin{tabular}{|c|c|c|c|c|c|c|c|c|c|c|}
\hline \multirow[t]{2}{*}{ State } & \multicolumn{4}{|c|}{ Persons Covered } & \multicolumn{4}{|c|}{ Activities Covered } & \multicolumn{2}{|c|}{$\begin{array}{l}\text { Signage } \\
\text { Required }\end{array}$} \\
\hline & Vets & Farriers & Spectators & $\begin{array}{l}\text { Non- } \\
\text { participant } \\
\text { landowners }\end{array}$ & Racing & Transporting & Breeding & $\begin{array}{l}\text { Pre- } \\
\text { purchase } \\
\text { Inspection }\end{array}$ & $\begin{array}{l}\text { Posted } \\
\text { Signs }\end{array}$ & Waivers \\
\hline Alabama & & $\mathrm{X}$ & & $\mathrm{X}$ & & & & $\mathrm{X}$ & $\mathrm{X}$ & \\
\hline Arizona & & & & $\mathrm{X}$ & & & & $\mathrm{X}$ & & $\mathrm{X}$ \\
\hline Arkansas & & & & $\mathrm{X}$ & & & & $\mathrm{X}$ & $\mathrm{X}$ & \\
\hline Colorado & $\mathrm{X}$ & $\mathrm{X}$ & & $\mathrm{X}$ & & & & $\mathrm{X}$ & $\mathrm{X}$ & \\
\hline Connect. & & & & & & & & & & \\
\hline Delaware & & $\mathrm{X}$ & & $\mathrm{X}$ & & & & $\mathrm{X}$ & $\mathrm{X}$ & \\
\hline Florida & $\mathrm{X}$ & $\mathrm{X}$ & & $\mathrm{X}$ & & & & $\mathrm{X}$ & $\mathrm{X}$ & $\mathrm{X}$ \\
\hline Georgia & $\mathrm{X}$ & $\mathrm{X}$ & & $\mathrm{X}$ & & & & $\mathrm{X}$ & $\mathrm{X}$ & \\
\hline Hawaii & $\mathrm{X}$ & $\mathrm{X}$ & & $\mathrm{X}$ & & & & $\mathrm{X}$ & & \\
\hline Idaho & & & & $X$ & & & & $X$ & & \\
\hline Illinois & $\mathrm{X}$ & $\mathrm{X}$ & & $\mathrm{X}$ & & & & $\mathrm{X}$ & $\mathrm{X}$ & $\mathrm{X}$ \\
\hline Indiana & & $\mathrm{X}$ & & $\mathrm{X}$ & & & & & $\mathrm{X}$ & \\
\hline Iowa & $\mathrm{X}$ & $\mathrm{X}$ & & $\mathrm{X}$ & & $\mathrm{X}$ & $\mathrm{X}$ & $\mathrm{X}$ & $\mathrm{X}$ & \\
\hline Kansas & $\mathrm{X}$ & $\mathrm{X}$ & & $\mathrm{X}$ & $\mathrm{X}$ & & & $\mathrm{X}$ & $\mathrm{X}$ & \\
\hline Kentucky & $\mathrm{X}$ & $\mathrm{X}$ & & $X$ & & & & $\mathrm{X}$ & $X$ & \\
\hline Louisian. & $X$ & $\mathrm{X}$ & & $X$ & & & & $X$ & $X$ & \\
\hline Maine & $X$ & $X$ & $X$ & $X$ & $X$ & $\mathrm{X}$ & $X$ & $X$ & $X$ & \\
\hline Massach. & $\mathrm{X}$ & $\mathrm{X}$ & & $X$ & & & & $X$ & $X$ & \\
\hline Michigan & $X$ & $X$ & & $X$ & & & $X$ & $X$ & $X$ & \\
\hline Minnesot. & & $\mathrm{X}$ & & $\mathrm{X}$ & & $\mathrm{X}$ & & & $X$ & \\
\hline Mississip. & $\mathrm{X}$ & $\mathrm{X}$ & & $\mathrm{X}$ & & & & $X$ & $X$ & \\
\hline Missouri & $X$ & $X$ & & $X$ & & & & $X$ & $X$ & \\
\hline Montana & $\mathrm{X}$ & $\mathrm{X}$ & & $X$ & & & & $X$ & & \\
\hline Nebraska & $\mathrm{X}$ & $\mathrm{X}$ & & $X$ & & & & $X$ & $X$ & \\
\hline N. Hamp. & $X$ & $X$ & & $X$ & & & & $X$ & & \\
\hline N.Jersey & $\mathrm{X}$ & $\mathrm{X}$ & $X$ & $\mathrm{X}$ & & $\mathrm{X}$ & & $\mathrm{X}$ & $X$ & \\
\hline N.Mexico & & & & & $\mathrm{X}$ & & & $X$ & $X$ & \\
\hline N.Carolin. & $\mathrm{X}$ & $\mathrm{X}$ & & $\mathrm{X}$ & $X$ & & $X$ & $X$ & $X$ & \\
\hline N.Dakota & & & & $X$ & & & & $X$ & & \\
\hline Ohio & $\mathrm{X}$ & $\mathrm{X}$ & & $\mathrm{X}$ & & $\mathrm{X}$ & $X$ & $X$ & & $\mathrm{X}$ \\
\hline Oklahoma & $X$ & $\mathrm{X}$ & & $X$ & $X$ & & & $X$ & & $\mathrm{X}$ \\
\hline Oregon & & & & $X$ & & & & $X$ & & $\mathrm{X}$ \\
\hline Pennsylv. & & $\mathrm{X}$ & & $X$ & & & $X$ & $X$ & $X$ & \\
\hline Rhode Is. & $X$ & $X$ & & $X$ & & & & $X$ & $X$ & \\
\hline S.Carolina & $\mathrm{X}$ & $\mathrm{X}$ & & $\mathrm{X}$ & & & & $X$ & $X$ & \\
\hline S.Dakota & $X$ & $X$ & & $X$ & $X$ & & & $X$ & $X$ & \\
\hline Tennes. & $X$ & $X$ & & $X$ & & & & $X$ & $X$ & \\
\hline Texas & $\mathrm{X}$ & $\mathrm{X}$ & & $\mathrm{X}$ & & & & $X$ & $\mathrm{X}$ & \\
\hline
\end{tabular}




\begin{tabular}{|l|l|l|l|l|l|l|l|l|l|l|}
\hline State & \multicolumn{4}{l|}{ Persons Covered } & \multicolumn{3}{l|}{ Activities Covered } & \multicolumn{2}{l|}{$\begin{array}{l}\text { Signage } \\
\text { Required }\end{array}$} \\
\hline & Vets & Farriers & Spectators & $\begin{array}{l}\text { Non- } \\
\text { participant } \\
\text { landowners }\end{array}$ & Racing & Transporting & Breeding & $\begin{array}{l}\text { Pre- } \\
\text { purchase } \\
\text { nspection }\end{array}$ & $\begin{array}{l}\text { Posted } \\
\text { Signs }\end{array}$ & Waivers \\
\hline Utah & & & & $\mathrm{X}$ & $\mathrm{X}$ & & & $\mathrm{X}$ & $\mathrm{X}$ & \\
\hline Vermont & & & & $\mathrm{X}$ & & & & & $\mathrm{X}$ & \\
\hline Virginia & $\mathrm{X}$ & $\mathrm{X}$ & & $\mathrm{X}$ & & & $\mathrm{X}$ & $\mathrm{X}$ & & $\mathrm{X}$ \\
\hline Washing. & & & & $\mathrm{X}$ & & & & $\mathrm{X}$ & & \\
\hline W.Va. & & & & $\mathrm{X}$ & & & & & & $\mathrm{X}$ \\
\hline Wisconsin & & & & $\mathrm{X}$ & & & & & & \\
\hline Wyoming & & $\mathrm{X}$ & & $\mathrm{X}$ & & & & $\mathrm{X}$ & & \\
\hline
\end{tabular}

Table 1 


\section{Chapter III \\ DUTIES OF THE ACTIVITY SPONSOR AND OWNER}

\section{Health and Safety of the Horse}

As stated in Chapter II, the horse owner and equine activity sponsor have certain duties to participants. These are well defined in many state statutes. The West Virginia statute states that horsemen have a duty to "make known to any participant any dangerous traits or characteristics or any physical impairments or conditions related to a particular horse which is involved in the equestrian activity of which the horseman knows or through the exercise of due diligence could know" (WV Code s 20-4-3). It is the responsibility of the horse owner to ensure that the animal is well cared for, properly vaccinated, and in reasonably good health. It is also the owner's responsibility to ensure that the animal is properly trained so as not to pose a danger to others that come into contact with the horse, and to warn participants of any dangerous propensities that the horse possesses.

All states have laws related to the humane treatment of animals and make it a crime to engage in certain types of cruelty toward animals. In West Virginia these are known as the cruelty to animals statutes. This set of laws addresses issues such as what constitutes cruelty, who in each county has authority to seize neglected and abused animals, and the penalties for such crimes. According to Chapter 7, Article 10 of the West Virginia Code (WV Code s 7-10-1), the sheriff of each county must designate annually a deputy to serve as the humane officer for that county. The county dog warden may also serve in this capacity if the county commission agrees to such an appointment.

The kind of treatment that constitutes cruelty is a subject of much debate within the legal system. The West Virginia Code describes conditions under which a person may be charged with animal cruelty. This includes "any person that cruelly mistreats, abandons or withholds proper sustenance, including food, water, shelter or medical treatment necessary to sustain normal health and fitness or to end suffering or abandons any animal to die, or uses, trains or possesses any domesticated animal for the purpose of seizing, detaining or maltreating any other domesticated animal" (WV Code s 61-8-19). A violation of this statute is considered a misdemeanor and punishable by up to six 
months in jail and/or a one thousand dollar fine. The code also includes as a form of cruelty "any person, other than a licensed veterinarian or a person acting under the direction or with the approval of a licensed veterinarian, who knowingly and willfully administers or causes to be administered to any animal participating in any contest any controlled substance or any other drug for the purpose of altering or otherwise affecting said animal's performance" (WV Code s 61-8-19). This is particularly applicable to the horse industry in which some horses are given painkillers, anti-inflammatory drugs, and other substances in order to enhance performance or disguise soundness problems.

In West Virginia and other states, it is the duty of the horse owner, equine activity sponsor, or caretaker to ensure that the animals are properly cared for, and that any conditions which might make the animal unsafe are fully disclosed. Failure to do so may be punishable under the cruelty to animals statutes and may also bar the owner or activity sponsor from liability protection under the equine activity statute. For example, many abused and neglected horses often display defensive behavior toward handlers due to previous traumatic experiences. This behavior can result in serious injury to persons handling the horse that are unaware of the propensity and history of the horse. In a case such as this, the neglect and cruelty of the owner is directly related to the injury. The owner has breached his or her duty to properly care for the horse and the duty to warn others about the horse's dangerous propensities.

Without the protection of the equine liability statutes those that sell or rent horses for public use and those that sponsor or provide facilities for equestrian activities would be subject to liability based on product liability laws. Product liability claims may be brought based on strict liability, negligence, or breach of warranty. There are three commonly argued categories of product defect. They include design defect, manufacturing defect, and warnings defect. Warnings defect is a failure to adequately warn of the risks associated with product use (Kaplan, 2006). If product liability laws were to be applied to equine related personal injuries, the argument would likely be a warning defect. Strict liability, negligence, or breach of warranty may all play a role in arguing cases of this sort. Of course it is recognized that horses are prey animals subject to sudden and unpredictable behavior which may not reasonably be foreseen by the owner, activity sponsor, or participant. For this reason, personal injury cases involving 
horses and other livestock animals are viewed differently in the eyes of the court. Persons who are injured due to the inherent risks associated with equine activities are barred from collecting under the equine activity statutes. This does not however protect horsemen who are found to be negligent or who breached their duty to participants.

Maltreatment of an animal may change the animal's demeanor and reactions to handlers in unforeseeable ways. This is why many animal adoption centers are reluctant to place stray dogs in homes with small children or other small animals. It is difficult to predict how an abused animal will react to certain stimuli. Horses are much the same in this regard. Rescue centers for ex-racehorses are usually well acquainted with this sort of dilemma. Often racehorses have been subject to aggressive handling, many different caretakers, and training methods which make them more fearful than the average horse. These horses may display defensive behaviors such as biting, striking, rearing, and kicking in response to unfamiliar surroundings or people.

Most adoption agreements for rescue centers contain statements similar to this one presented by an adoption center in New Mexico: “Adopter(s) hereby accepts the above-described horse as is, assumes all risks of ownership, including the risk of injury or damage. Adopter(s) hereby completely release The Horse Shelter from any claim, cause of action, or liability in connection with above-described horse, from above date. Adopter(s) agree to hold The Horse Shelter, its staff, volunteers, and agents harmless from any claim, cause of action, or demand of any sort as a result of the adoption of the above-described horse. The Horse Shelter hereby represents that it has disclosed any and all background, physical, and medical information known to The Horse Shelter about the above-described horse" (The Horse Shelter: Adoption Contract, 2005). Although the care and expense for adopted horses is the responsibility of the adopter, the center retains ownership of the horse and may reclaim the horse at any time due to neglect. This is one of a few instances where the legal owner of the horse may not be held responsible for injuries or damage caused by the horse if the injury occurred due to the negligence of the adopter, and this negligence was not known to the adoption center.

In cases where horses have been abused and neglected, the county in which the animals are found has the authority to seize the animals. Even in cases where no personal injury exists, defendants may still be held liable for any costs associated with the care of 
the seized animals, along with any misdemeanor charges that may be filed. In Browning

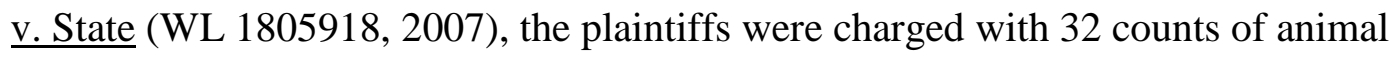
cruelty. Cass County, Indiana boarded and cared for several of the horses at a considerable expense. The county was able to collect nearly $\$ 14,000$ from the plaintiffs for the care of the horses while they were impounded.

Horses that are untrained or are not accustomed to being handled also pose a danger to others, even though they may not have ever suffered maltreatment. In these instances it is the duty of the owner or caretaker of the horse to diligently warn others of the horse's propensity to misbehave. In the 2005 case of Dodge v. Durdin(WL3214618, 2005) the Texas Court of Appeals reversed the lower courts finding of summary judgment. In this case the plaintiff, an employee of Durdin, was injured when she was kicked in the abdomen while attempting to administer medical treatment to an untrained colt. The lower court found in favor of the defendant on summary judgment stating that Dodge was a participant in an equine activity at the time of her injury; therefore Durdin was protected under the Texas Equine Activity Statute (Tex. Stat. s 87.001). On appeal this decision was reversed based on two issues of fact. The first was that Dodge was not considered a participant in an equine activity because she was a paid employee of Durdin, therefore the equine activity statute did not apply. The second was that Durdin did not provide sufficient warning of the colt's dangerous propensities. The court found that Durdin's statement to the plaintiff that the colt "had not been handled much" (WL3214618 p. 3, 2005) did not adequately describe the colt's behavior and background in that Durdin failed to mention that "the horse was not trained, that it previously resided only in a pasture, that it was dangerous, that she should pay close attention to it, that it needed to be handled with care, and that she should be calm around it".

Generally horses are thought to be less aggressive toward human handlers than dogs, even in cases where the horses have been abused or neglected. There are many more cases involving vicious propensities of dogs than horses. Dogs tend to display attack behavior in response to maltreatment and abuse more often than horses. However, the duty of the owner, regardless of species, is the same. If the animal is abused, and as a result develops dangerous propensities, the owner must disclose these propensities to those who come into contact with the animal. In some instances the animal's demeanor is 
such that it cannot be safely placed into another home and must be euthanized. In these cases it is often difficult to prove that the aggressive behavior is the direct result of the abuse. In the Ohio case of Southall v. Gabell (293 N.E.2d 891, 1972)the plaintiff brought suit against the transporter of his three year old racehorse. After receiving surgery for the repair of bone chips in the horse's front legs, the horse was transported to the wrong stable by mistake by Gabell. Upon discovering this, Gabell loaded the horse to deliver it to the owner at the proper stable. In route to the second location the horse became very excited and nervous on the trailer. Gabell stopped and gave the horse a tranquilizer, which it had never required before. Upon arriving at the owner's stable the horse was visibly upset, sweating, and had wounds on his hips and legs. After recovering from his injuries, the owner reported that the horse was never the same again and became a "killer horse", displaying vicious behavior to all who attempted to come near him. This behavior worsened until the horse had to be put down. The owner sued the transporter for damages. This case was dismissed by the Ohio Municipal Court because "what caused the horse to become a 'killer' was speculative” (293 N.E.2d 891 p. 1, 1972).

In order to help ensure the healthy and humane transportation of animals and to combat communicable diseases, the West Virginia Code requires that any domestic animal entering the state be accompanied by a health certificate issued by a licensed veterinarian within the previous 30 days (W.Va. Code s 19-9-21. Currently there are no laws in West Virginia restricting the time period in which animals are permitted to be on trailers, nor are there laws specifying how often the animals are to be fed and watered during transit. However it is the duty of the horse owner to make reasonable efforts to ensure the health and safety of the animal and the duty of the transporter to fulfill their obligation and not cause undue harm to the animals. Therefore the burden of safe transport falls to the owner in terms of selecting a qualified person to transport the animals. If the transporter is negligent, resulting in injury or death to the animal or others, both the horse owner and transporter may be held liable for damages.

\section{Hazardous Conditions and the Landowner}

Just as it is the duty of the equine activity sponsor to disclose information about a particular horse, it is also their duty to disclose any information about the facilities and 
property that may contain a hazard for participants. This is important for landowners who provide land or facilities for organized equestrian activities. If landowners are aware of a dangerous condition on the property, such as an old well, they are required to disclose this to participants. Not doing so may bar them from the protection of the equine activity statute. Many people falsely believe that they are protected from liability for injuries that result from any type of horse riding accident that occurs on their property due to the inherent risks of riding horses. As was discussed in Chapter II, the protection of the equine activity statutes in most states extends only to organized equestrian activities. This does not include going for a trail ride on your own personal horse, and many times does not include inviting friends over to your house to ride with you. In $\underline{\text { Carl v. Resnick }}(714$ N.E. 2d, 1999), as cited previously, the court found "that plaintiff's complaint against defendant was not barred by the Equine Act unless plaintiff's recreational riding of her own horse on a public trail was one of the limited activities sought to be encouraged by the Act" (714 N.E. 2d p.1, 1999). This leaves the question of which laws apply in cases of injury that do not fall within the parameters of the equine activity statutes.

In terms of accidents resulting from hazardous conditions located on the property of the landowner, several things must be determined. First is the question of whether or not the incident occurred during an organized equine activity. In West Virginia, as with most other states, this includes activities such as shows, parades, rodeos, sanctioned trail rides, hunt trips, activities at public stables, and other organized events. If the activity in question is not considered an equine activity as described in the statute, then the question is whether the participant paid a fee to the landowner to use the property. In cases such as this, West Virginia's Recreational Use Statute applies. Chapter 19 of the West Virginia Code (WV Stat. s 19-25) provides liability protection for landowners that allow others to use their land and water areas for military training or recreational or wildlife propagation, so long as the user was not charged a fee to do so. The statute states that "an owner of land owes no duty of care to keep the premises safe for entry or use by others for recreational or wildlife propagation purposed, or to give any warning of a dangerous or hazardous condition, use, structure, or activity on such premises to persons entering for such purposes" (WV Stat. s 19-25-2). 
In most states, there are three main categories applied to users of land. They are trespassers, licensees, and invitees. The duty of care that a landowner owes a trespasser is very limited (Uchtmann, 1981). Generally the duty is simply to not cause intentional harm to trespassers. For example if a landowner attempted to discourage horseback riding on his or her property by digging a dangerous trench or constructing a hidden trap in places that were known to be used by horseback riders, the landowner would be held liable for injuries even though the riders were trespassing at the time of the accident.

The degree of duty owed to a licensee is somewhat higher. Licensees are those that enter onto someone else's property with permission, for his or her own purpose or business rather than for the benefit of the landowner. Social guests and insurance salesmen would be examples of licensees. In many states, the duty of the landowner is to warn licensees of any dangerous condition or animal that may be encountered while using the property. In Hussey v. Seawell(527 S.E. 2d 90, 2000) the plaintiff was asked to move two horses from one pasture to another by Seawell. Hussey was unaware that the gate into the new pasture had recently been modified to close automatically. As she led the two horses into the field the gate closed, spooking one of the horses. The horses reared and struck Hussey in the face, causing substantial injury. The North Carolina Court of Appeals found that based upon her previous experience with the gate, Hussey could reasonably assume that the gate would remain open. A jury found that Seawell's failure to warn Hussey of the modification of the gate was the proximate cause of the injury. As provided by the recreational use statute however, West Virginia landowners are not required give warning of hazardous conditions to those entering the property as licensees.

The highest degree of duty required of landowners is to invitees. Invitees are those people that enter a premise for a purpose related to the landowner's business. This would include all those who enter public riding stables for the purpose of engaging in group trail rides. In these cases the property owner has a duty to make reasonable inspections of the property for hidden dangers and either correct the dangerous condition or clearly warn invitees of its presence. Contributory negligence and assumption of risk become important defenses here in terms of limiting the liability of landowners. This is where the presence of a signed release may show that the participant knowingly accepted 
the risks associated with the activity, so long as those risks were outlined clearly in the waiver.

In many cases involving horse accidents it can be successfully argued by the defendant that the injured person had sufficient knowledge of horses so as to be aware of the propensity of horses to react suddenly and unpredictably to a stimulus. However if the accident resulted at least partially because of a negligently maintained facility or an unmarked hazard, the landowner may still be held partially or wholly liable. In Alaimo v.

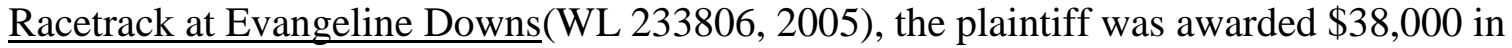
damages when his racehorse collided with a negligently maintained gate along the racetrack during a training ride. The horse was euthanized as a result of the accident, and the Louisiana Court of Appeals awarded the plaintiff damages based on the projected future winnings of the horse.

In many cases inspection of the facilities and property may not reveal a hazard that exists. It is only as a result of the accident that the hazard becomes known. In these cases the genuine lack of knowledge of the presence of the dangerous condition by the landowner may protect them from liability. The equine activity statutes in each state may also supersede the duty of reasonable inspection in some instances. For example in the 2001 Ohio case of Allison v. Johnson (WL 589384, 2001)the plaintiff was injured when the horse she was observing in the ring began to back up causing it to back into a gate. The gate popped out of the bracket injuring the plaintiff in the face. Allison sued stable owner Johnson for negligence. The Ohio Court of Appeals found that under the Ohio Equine Activity Statute the plaintiff was a participant in that she was a "spectator of an equine event", and that the stable owner could not have reasonably foreseen that a horse backing into the gate would cause the gate to become dislodged from the bracket.

In cases where the landowner and injured party were not engaged in an equine activity as defined by the statute, the hazardous condition must be known to the landowner, or through due diligence should have been known, and reasonably foreseen. This may be difficult for the plaintiff to prove. In Baker v. McIntosh(132 S.W.3d 230, 2004) the court ruled in favor of the defendant when his colt fell against a trailer door which struck a visitor, causing injury. The Kentucky District Court found that the colt's 
owner had no duty to prevent the colt from falling against the trailer door, nor did he have a duty to the visitor to warn that such an accident might happen.

One common hazardous condition that is often overlooked by landowners is the presence of dogs. Dogs can spook, chase, or even attack horses at substantial risk to riders. In some instances the presence of a dog is not enough to require a warning to horseback riders, as dogs are commonly found around and near stables. The presence of a dog in most instances is a foreseeable risk associated with the equine activity. However if the dog displays vicious tendencies or aggressive behavior toward the horses or riders, and no effort is made by the landowner to control or confine the dog, the owner may be held liable. Under common law, dogs are viewed in a manner very similar to horses, based upon their past behaviors and propensities, sometimes referred to as the "one-bite" rule (Clarke-Dawe, 2003). Many states apply strict liability for dog bite incidents in cases where the dog attacks a human. This does not apply when the dog attacks a horse, causing a person to be bucked off and injured. West Virginia, and other states such as Ohio, applies strict liability for any damage to persons or property caused by dogs that are running at large. In Gibson v. Donahue (722 N.E. 2d 646, 2002), a woman was injured when she was riding her horse through a city park. The defendant Donahue owned two Irish Setter dogs which she allowed to run loose, despite the sign posted in the area that the park was "restricted to equestrian use only" (722 N.E. 2 d 646 p. 2, 2002). The dogs began chasing the horse, causing Gibson to be thrown into a tree where she sustained serious injury. The Ohio Court of Appeals ruled that Donahue was liable for any injury or damage caused by her dogs as a result of the dogs being allowed to run loose. If the dog is not running free then the plaintiff must show knowledge by the owner of the dog's previous dangerous behavior to prove negligence.

In cases where a dog attacks a horse, causing the horse to injure the rider or handler, plaintiffs may make their argument based on the state's dog bite statute and on the owner's negligence to control the animal. Most often the dog bite rule will not apply because this requires that the dog directly bite the human, not the horse. This was evidenced in the 1997 case of Nickell v. Summer(943 P. 2d 625, 1997). In this case, Summer visited Nickell for the purpose of test riding a horse that Nickell had for sale. During the ride Nickell's Doberman Pinscher attacked the horse causing it to buck 
Summer off. Summer argued using both a negligence action and claimed that the Oklahoma dog bite rule applied. The jury found that even though the dog bite rule did not apply, the owner was still negligent in his failure to control the dog.

A loose or escaped horse is a dangerous hazard for bystanders, motorists, and the horse owner. Loose animals are dealt with in different ways by the law, depending upon what part of the country the accident occurs in. There are two basic theories of liability for loose or escaped livestock in the United States; negligence and open range laws (Clarke-Dawe, 2003). Currently, negligence is the system applied in most states and is the most restrictive in terms of assigning damages. In states that apply this theory, livestock owners are held liable for any damages that occur as a result of their animals being loose due to the owner's negligence. Here the primary issue is whether or not the animal was properly confined as defined by the individual state laws that apply. West Virginia and New Hampshire are states that impose liability to owners of animals that are negligently permitted to run loose. These states have specific laws regarding stallions. Chapter 467 of the New Hampshire Code states that "any owner or keeper of a stallion more than 12 months old, who willfully or negligently permits such stallion to run at large, out of the enclosure of such owner or keeper, shall be guilty of a violation"(New Hamp. Code s 467:1-a). The West Virginia Code contains several sections which describe the damages assigned to owners of loose livestock, and gives special mention to the "unlawful running at large of certain male animals and swine"(W. Va. Code s 19-183).

In most states the duty falls on the livestock owner to construct and maintain an appropriate fence to keep their livestock in. Failure to properly maintain the fence or knowingly allowing animals to run at large creates a hazard and may be grounds for liability. In the majority of states, these laws have been modified from English common law and have been in existence for many years. If the plaintiff can prove that the defendant knew the animals were running loose and did not attempt to confine them, the fence was negligently maintained, or that the animals had a history of repeatedly escaping, the defendant may be assigned damages based on negligence. In the 1982 South Carolina case of Reed v. Clark (286 S.E. 2d 384, 1982), the Supreme Court determined that Clark was negligent when three horses owned by him escaped onto a 
highway. Two of the horses were struck by a car driven by Reed. In Reed's argument he was able to prove that the horses had escaped on at least five other occasions by crushing down the wire fence that was used to contain them.

There are 13 states that currently apply some type of open range law regarding the fencing of livestock. In these states, with some variation, it is the responsibility of the citizens to fence out unwanted livestock, not the livestock owner's duty to fence them in. Texas, the Dakotas, Oregon, and Arizona are examples of states that use the open range system. In these states, the damage caused by livestock running at large is the responsibility of the owner of the damaged property. The most common application of this occurs when livestock are hit by motorists on the highway. Many times in these states when an animal is hit by a car, the damage to the car, any injuries sustained, and possibly restitution for the livestock is the responsibility of the driver. In Hubbard v. Howard (758 F. Supp.594,1990) an Idaho resident collided with several horses on a highway, causing the driver's death. Because Idaho is an open range state, the case was dismissed.

States such as Montana apply a modified version of the open range law. Here, it is the responsibility of the livestock owner to fence animals off of highways, and more populated areas within the state are designated non-open range districts in which the negligence laws used in eastern states apply. In Larson-Murphy v. Steiner (15 P. 3d 1205, 2000) the Montana Supreme Court ruled in favor of the defendant in an accident involving a collision with an Angus bull on a highway. The court found that open range laws in Montana do not apply when the accident involves a motor vehicle on a highway.

As discussed, in the majority of cases, with the exception of open range laws in a few states, it is the duty of the landowner or horse owner to ensure that reasonable care is taken to avoid hazardous conditions and that hazards are made known to equine activity participants. Though negligence may be difficult to prove, it is advantageous for the landowner or activity sponsor to fully disclose any conditions of the property or facility which may pose a threat to the safety of the participants and their horses. It is also the duty of the landowner to avoid constructing or creating hazards in areas known to be used by others, and to avoid correcting hazards in a negligent manner that may result in a hidden danger, such as inadequately filling in a ditch that may collapse when stepped on. 
The most effective method of avoiding liability with regard to hazardous conditions are posted warnings, flagging on dangerous areas, disclosure of hazards in a waiver or other written form, and properly confining dogs, horses, and other livestock.

\section{Dangerous and Known Propensities}

One of the most common arguments made when someone sustains injury during a horse riding accident is that the horse had a prior history of dangerous behavior that was not disclosed to the rider. In general, it is the duty of the horse owner or caretaker to fully disclose any information known about the animal which may make it unsafe to riders or potential buyers. The term 'propensity' is commonly used regarding the behavior of animals and liability, meaning the animal's tendency to engage in a specific behavior. In order to prove a dangerous propensity, the behavior must be unusual for the animal in question. For example, it would not be considered a dangerous propensity for a horse to spook if the rider waved a hat or shirt over the horse's head while mounted. Spooking in this case would be regarded as normal behavior for any horse in this situation (Dawson, 2006). Of course, any horse may kick, bite, strike, buck, or rear under certain circumstances. The owner cannot, nor are they expected to, predict what the horse will do in the future if the horse has no known tendency to misbehave. Propensities are abnormal tendencies for a specific animal to react to a certain stimulus. In order to assign liability in dangerous propensity cases, it must be proven that the animal had the propensity, that this propensity was know or should have been known to the owner and was not disclosed to the injured party, and that this propensity was the proximate cause of the injury.

Each year many horses are sold at public auction. In these instances often the buyer does not have the opportunity to speak to the horse seller. The seller may not even be present. It is generally understood that buyers are purchasing these horses "as is", and that the horses may have dangerous propensities which are not disclosed. As long as no statements are made about the horse by the seller in order to intentionally mislead the buyer, it is nearly impossible to prove negligence in public auction cases (Dawson, 2006).

The seller of a horse by private contract has a higher duty to the potential buyer in terms of relaying information about the horse. In these cases, it is not excusable for the owner to remain silent about a known dangerous propensity of the horse in question. 
Most states address this specifically in their equine activity statutes. As previously cited, the West Virginia statute contains specific language regarding known propensities. The West Virginia statute states that horsemen have a duty to "make known to any participant any dangerous traits or characteristics or any physical impairments or conditions related to a particular horse which is involved in the equestrian activity of which the horseman knows or through the exercise of due diligence could know"(W. Va. Code s 20-4-3). However the wording of this statute does not include the selling of horses or the riding of a horse in a pre-purchase trial as equine activities. Still, knowingly withholding information about an animal that results in injury may be grounds for negligence.

There are several acceptable methods of providing warnings about a horse's dangerous propensities. Many public riding stables post signs on the stall doors of horses that are known to bite. Choosing to send a horse to a professional trainer in an effort to eliminate the unwanted behavior is also widely acceptable. It is advisable in these situations to obtain a written statement from the trainer that he or she believes the behavior has been eliminated prior to the horse being returned to general use. A commonly used method of warning is to tie a red ribbon in the tail of a horse that has a propensity to kick and is widely known among horse riders. Verbal warnings of a horse's behavior are also acceptable; however it may be more advantageous for the owner to put the warning in writing or to have a witness present when the verbal warning was given. The use of the phrase "should have known" in many state statutes does not require proof of direct knowledge of the horse's behavior. It only requires proof that any reasonable person in the owner's position should have been aware of the propensity. This discourages horse owners from turning a blind eye to the behaviors of their animals in order to argue a lack of knowledge.

There have been many case examples in the past several years regarding the dangerous propensities of horses and personal injury claims. The standard argument made by plaintiffs is often that the horse owner was aware of the propensity of the horse to misbehave and did not disclose this to the rider or handler, resulting in their injury. It may be difficult to prove however that the owner was aware of the behavior, or that this behavior was the proximate cause of the injury. In Balen v. Peltier (WL 163518, 2006), the Court of Appeals of Minnesota gave summary judgment to the defendant when 
plaintiff Balen was injured while riding a horse owned by Peltier. Balen argued that Peltier knew that the horse was "high spirited, seldom ridden and was difficult to control". During the trial, Balen was unable to prove that Peltier had any knowledge of the horse's dangerous propensities and that he had no duty to warn her that the horse might rear and throw her off.

In a similar case in Georgia, the court applied the state's dangerous-animal statute because the participant was not engaged in an equine activity as defined in the equine immunity statute. In Burns v. Leap (645 S. E. 2d 751, 2007), the court ruled summary judgment for the defendant. In this case a woman was injured during a visit to a friend's house. Leap invited Burns and her family over to see her house and pastures. During the visit the two women, along with Burns' husband and children entered a pasture containing several of Leap's horses. As they walked into the pasture Leap asked Burns if she closed the gate behind them. Burns replied that she had not and offered to go shut it. As she did this, one of the horses began trotting towards her. Leap yelled to her to 'not let the horse out' and instructed her to wave her arms in an attempt to stop the horse (645 S. E. 2 d 751 p. 3, 2007). Burns did as she was instructed; however the horse did not stop, but instead knocked Burns into a barbed wire fence resulting in injuries to her face, head, arms, and wrist. During the hearing, Leap testified that she had never observed that particular horse running toward someone in that manner, nor had ever had any incidents involving injury with that particular horse. Burns was unable to prove otherwise, and the case did not make it to trial.

\section{Matching the Horse and Rider}

In the West Virginia equine activity statute, one of the conditions required in order for activity sponsors to receive full protection from liability is that they "make reasonable and prudent efforts to determine the ability of the participant to safely engage in the equestrian activity, to determine the ability of the horse to behave safely with the participant, and to determine the ability of the participant to safely manage, care for and control the particular horse involved" (W. Va. Code s 20-4-3). Most of the other equine activity statutes also make this a requirement in order to protect the sponsor from liability. Some statutes are more specific regarding the sponsor's duty to assess the 
participant's skill level. In some instances it is required that the sponsor interview the participant about their previous horse experience, while other statutes state that it is inadequate to rely solely on the participant's representation of their own skill level. In any case, matching a green rider with a green horse will most likely be viewed as negligence. Often one of the main issues in cases of beginner rider injuries is whether the rider knowingly assumed all the risks involved with horseback riding, and whether the injury was due to the negligence of the activity sponsor to pair the rider with a beginner level horse. Though it may be believable that a beginner would not fully comprehend that the horse they are riding might throw them off and cause injury, riders that have some experience with horses often cannot make this same argument.

In cases where injury occurs as a result of a novice riding or caring for a horse that requires a more experienced person, the legal theory used by the plaintiffs is referred to as 'negligent entrustment' (Clarke-Dawe, 2003). This means that the defendant was sued for negligence in entrusting the horse to a rider with an inappropriate skill level. In cases where the rider refuses the advice of the activity sponsors or intentionally misrepresents his or her skill level, it may be that this act of the participant contributed more than $50 \%$ to the injury. This would bar the plaintiff's claim of negligence by the activity sponsor. In the 2007 case of Clyncke v. Waneka(WL 570412, 2007), an inexperienced girl was injured when she was thrown from a horse that was loaned to her to ride on a roundup at a friend's ranch. The plaintiff filed suit against Waneka, alleging negligence. The Colorado District Court ruled in favor of the defendant, stating that the injury was a result of the inherent risks associated with horseback riding, thus Waneka was protected under the Colorado Equine Activity Statute. On appeal, this decision was reversed. Here the plaintiff argued that the defendant had a two-pronged duty with regard to assessing her capability according to the statute. The first requirement was that Waneka make a prudent effort to determine the ability of the participant to engage safely in the activity, and secondly that Waneka determine the participant's ability to manage the particular horse. Due to the issues of fact regarding whether or not Waneka met these duties, the case was remanded to the lower court for decision. It is interesting to note that the Colorado statute is somewhat unique in that the breach of one of the duties of the 
sponsor is not enough to hold them liable. It must be proven that the sponsor breached all of the duties in order for the court to find negligence.

In some cases a participant may present themselves to be more competent to ride a particular horse than they actually are. In these instances it is duty of the horse owner or activity sponsor to make a reasonable effort to match the rider to a suitable horse based on the participant's alleged skill level and also by observing the rider with the horse to make a determination. If the rider displays nervousness or apprehension about riding the particular horse, this should serve as a warning to the owner that perhaps the rider is not experienced enough to take part in the activity. In the case of Stoffels v. Harmony Hill Farm, (WL 3699549, 2006), the representation of the rider about her skill level may not have been sufficient to limit the defendant's liability. In this case, the defendant owned and trained close to 20 Thoroughbred horses for track racing and foxhunting. These horses ranged in size from 15 hands to over 17 hands. In need of additional riders, the owner decided to ask a local horse riding club if they had any members that were willing to exercise some of her horses. One woman, Stoffels, responded to this request. She sent an email to the owner in which she described in detail her many years of experience in riding and training Morgan horses. In this email she described herself as " 5 ' 1 " and stocky", she also stated that she was 65 years old and had a touch of arthritis, therefore would prefer a smaller horse to ride. The owner agreed to allow the plaintiff to ride with her. The plaintiff arrived and was presented with a mare to ride named Glory who was green broke and had been ridden less than 30 times. Glory was 17 hands tall and was described as being very broad. Upon seeing the mare, Stoffels remarked that perhaps this horse was too big for her to ride, but was told by the defendant that Glory was the smallest horse she owns. The defendant suggested that Stoffels ride the mare around in the ring to see if she would be comfortable with her before they went out on the trail. Stoffels then rode the mare in the ring, walking and trotting for about ten minutes. She found the mare to be responsive and well behaved so they left the ring and proceeded with the ride. At some point in the ride, while maneuvering around a large stump, Glory unexpectedly began to buck and threw Stoffel to the ground causing multiple injuries that required surgery. Stoffels filed suit alleging that the horse owner was negligent in her failure "to make reasonable and prudent efforts to determine the participant's ability to 
safely manage the particular equine animal, based on the participant's representation of his ability" (WL 3699549, 2006) as required by the New Jersey Equine Activity Statute (NJ ST s 5:15-9), and also that the defendant neglected to disclose that Glory was green broke and had not been ridden much. The defendant filed a motion for summary judgment, arguing that she fulfilled her responsibility in assessing the plaintiff's experience by relying on Stoffels' email account of her skill level and by observing Stoffels in the ring prior to the ride. Summary judgment in this case was denied. In its decision, the court stated that "We recognize that a fall from a horse is an inherent risk of horseback riding. On the other hand, the immunity offered by the statute is not absolute. The failure to take reasonable measures to match the rider to a suitable mount falls easily within exception (d) of the Act as "an act or omission on the part of the operator that constitutes negligent disregard for the participant's safety...." N.J.S.A. 5:15-9(d). Here, we are not satisfied that defendant's conduct in assigning Glory to plaintiff is so onesided that a reasonable jury would not find her negligent”' (WL 3699549 p. 4, 2006).

Public riding stables and stables that offer guided trail rides are often at the most risk for liability. In these situations there are many riders each day that have varied skill levels, some of whom have never been on a horse before. In most states, the stable is required to assess the rider's skill level prior to matching them to a suitable horse to ride. This task can be difficult, given the unpredictable nature of horses and the possibility that the person might represent their skill level inaccurately. In cases where the rider refuses the advice of the activity sponsors or intentionally misrepresents his or her skill level, it may be that this act of the participant contributed more than $50 \%$ to the injury. This would bar the plaintiff's claim of negligence by the activity sponsor. In the 1996 case of Deans v. Nebraska(unpublished, 1996)_, Deans, an experienced horseperson, along with several other people, signed up for a group trail ride. As the wrangler was preparing for the ride she instructed the participants to choose any horse they wanted except for Chip. The wrangler began assisting others with their horses. When she turned back around she saw that Deans was on Chip. She asked him to get down and explained that Chip had bucked earlier in the day. Deans was determined to ride the horse, so the wrangler instructed him just to follow the other horses. Ignoring this advice, Deans was heard to have remarked that he was "going to give this horse an attitude adjustment" (unpublished, 
1996). Chip then reared up and fell over on top of Deans, injuring him. The Nebraska Appellate Court ruled in favor of the stable, stating that short of physically grabbing Deans and removing him from the horse, the wrangler did everything she could to prevent the accident.

In many cases the jury can consider the experience level of the rider in determining liability. For example, a rider that is very experienced would have a more difficult time proving that the horse was unsuitable for them than someone who has little riding experience. In Wardrop v. Koerner (617 N.Y.S. 2d 964, 1994), Wardrop applied for a job exercising Thoroughbred racehorses for the defendant. Koerner asked Wardrop to ride Scott, a two year old horse, in order to assess Wardrop's skill level. Once they were both mounted, Koerner asked Wardrop to ride Scott alongside her on her horse, something Scott had never done before. Scott became very upset and threw Wardrop. Wardrop filed suit claiming that Koerner was negligent in placing her on a green broke horse without properly evaluating her qualifications to handle the horse. The New York Court of Appeals ruled in favor of the defendant, stating that Wardrop presented herself as a very experienced rider, and that if she had gotten the job, Scott was one of the horses she would be expected to exercise. Due to the high level of expertise Wardrop claimed she had, Koerner could have reasonably assumed that Scott's behavior would not be too much for her to handle.

\section{Avoiding Breach of Duty}

In order to avoid liability for injuries sustained by participants it is necessary that horsemen be aware of the duties required of them by the law. In West Virginia, the equine activity sponsor or horse owner is required to meet a specific set of criteria to be protected by the equine activity statute. This includes (1) making reasonable and prudent

efforts to determine the ability of a participant to safely engage in the equestrian activity and the ability of the horse to behave safely; (2) to make known to any participant any dangerous traits, characteristics, or physical impairments of the particular horse which the horseman should know; (3) make known any dangerous conditions of the land or facility by advising participants in writing or by posting warning signs; (4) make reasonable and prudent efforts to inspect tack and equipment for safe use; and (5) to prepare and present 
to each participant for his or her inspection and signature a statement which clearly and concisely explains the liability limitations set forth in the statute (W. Va. Code s 20-4-3). Most other states have similar requirements of activity sponsors.

Though a waiver is required in West Virginia, it is not required in most other states. Having a well written disclaimer may not only bar a plaintiff from claiming negligence, it may also show that the participant knowingly assumed the risks associated with the equestrian activity. Honesty is the best policy when constructing disclaimers and when providing information about a horse to a participant or potential purchaser. The horse owner or activity sponsor should clearly outline the foreseeable risks associated with horseback riding, any known propensities of the horse, any hazardous conditions on the land or facility, and any other conceivable information that might aid in preventing injury. Though not required by West Virginia law, it is also advisable to request that participants wear helmets. Not only will this help in preventing serious injury, but it may aid in showing that the activity sponsor was conscientious in trying to protect the participants. The participant also has a duty to accurately and honestly portray his or her abilities regarding handling the horse. Stable owners that offer public riding should have a written policy involving the inspection of tack and equipment. If a piece of tack breaks or is faulty, it may help to show that the tack was inspected regularly and that the faulty equipment was not a pre-existing condition. 


\section{Chapter IV \\ DISCLAIMERS FOR LIABILITY PROTECTION}

\section{Uses and Forms of Disclaimers}

It has been said many times that a liability waiver is 'not worth the paper it was written on'. This may be the case if the release is poorly written or is constructed in such a way that its application would be illegal. However, in many cases the presentation of a signed waiver in court will greatly decrease the chances of being held liable for participant injuries. In some states, such as West Virginia, the presentation of a waiver for the participant's signature is not only advisable; it is required in order to be afforded protection under the equine activity statute. The use of releases is commonplace in recreational activities. The vast majority of stables that offer trail rides or lessons for the public will present some type of liability waiver to be signed prior to engaging in the activity. Many times plaintiffs argue that it is unfair to require the signing of a waiver in order to participate or that they did not read the waiver or did not realize what they were signing. Sometimes these arguments are effective, based on the individual circumstances surrounding the accident. It is important to know what should be contained in the wording of the disclaimer and under what conditions the disclaimer may not provide protection.

Generally disclaimers in equestrian activities come in three forms: posted signs, liability waivers for signature, or as statements within sale contracts. Regardless of the format, the intent is the same. Waivers are used to prevent a plaintiff from winning a law suit against the defendant, or to discourage the participant from filing a law suit in the event of an injury. It is usually advisable to have an attorney write the disclaimer in order to help ensure its effectiveness. Most courts view disclaimers very critically and tend to view the scope of disclaimers in a narrow interpretation. Currently 27 of 45 states that have an equine activity statute mention the use of disclaimers. West Virginia is one of a minority of states that require a signed waiver, however many other states require the posting of signs in easy to spot locations around the stable. Most states that require the posting of a sign also require that the sign contain the wording included in the statute regarding liability and the risks associated with the activity. Regardless of the wording, 
most states will not uphold a release if the owner or activity sponsor was negligent, even if the release permits negligence by the parties involved. Generic releases are easily accessible and many can be downloaded from the internet. This is not usually advisable for several reasons. The person who wrote the release may not be an attorney and may have limited knowledge of the law. A generic release is less likely to contain the specific liability limitations of the individual state in which it may be used due to the significant variation among state laws. Also the release may not provide the individual protection necessary for equestrian activities, and likely will not thoroughly outline all of the risks unique to dealing with horses. Further, the release may have been drafted years ago, and therefore may not comply with current legal developments. For these reasons, drafting a thorough and well written release is essential for optimal protection for the equine activity sponsor.

Junior riders may require special consideration when using disclaimers. In states where the posting of a sign is the only requirement, it may still be beneficial to present a waiver for signature by the parent or guardian. Children cannot be expected to read and understand liability signs, therefore cannot knowingly consent to assume all of the risks associated with riding. The signature of a junior alone, without the signature of the parent or guardian as well, will void a contract. In cases where a parent signs a release allowing the child to participate in an activity, and the child is killed as a result of injuries sustained during the activity, the signed waiver will not necessarily prevent the parent from bringing a lawsuit. In Meyer v. Naperville Manner (262 3d 141, 1994), a ten year old child sustained serious injury while receiving a horseback riding lesson. Though the child's mother had signed a waiver, the Illinois Appellate Court found that the waiver barred the mother's claim only, but did not bar the child's claim. In the event that the child had been killed, the parents could have filed a suit as legal representatives of the child. Everyone has a legal right to sue for injuries. Even if a parent signs a release stating that they will not file a suit against the activity sponsor, had the child lived, the child would have a legal right to file a suit. This right is not terminated upon the death of the child. In the event of a death, the estate of the child would have a legal right to sue, and in most cases, the parents are in charge of the estate. Therefore they may file a lawsuit on behalf of the child (Clark-Dawe, 2003). 
When horse owners invite friends over to ride, most would not present a waiver for their friends to sign. This may leave the horse owner open to a liability law suit. In most states riding someone else's horse and riding your horse on someone else's property are not considered equine activities, thus would not be covered under the equine liability statute. In order to be considered an equine activity in West Virginia, the event must be organized, sanctioned, open to the public, or part of the operation of an equine business. Many horse owners incorrectly assume that they cannot be sued for any accident involving horses because they are fully protected by the equine immunity laws. This leads to a false sense of security in that many horse owners do not become familiar with disclaimers, and most do not post signs regarding the risks associated with horses. Also many horse owners assume that disclaimers will not stand up in court, and so are useless. The critical distinction in whether or not a release will protect the horse owner is often in how the hold harmless clause within the release is worded.

\section{$\underline{\text { Content and Wording of Disclaimers }}$}

As stated previously, virtually no release will protect the horse owner, activity sponsor, or land owner from liability in cases where they were obviously negligent. Disclaimers that contain statements such as "not liable for injuries or death under any circumstances", or "management is not responsible for any injuries resulting from negligence", will likely not provide protection. This is because in most states, negligence is a tort or civil wrong. Any statement that intends to permit negligence would be a violation of tort law. In order to be most effective for equestrians, the disclaimer must contain several elements. These include a clear and concise description of the risks associated with the activity, a specific and thorough list of all those intended to be covered by the disclaimer, a list of the types of activities the release is designed to cover, and special considerations for children if applicable. The owner should also make certain that participants are aware that they are signing a release of liability, and this should be written clearly at the top of the contract. It is essential to have a clear understanding of the wording of the equine activity statute in the individual state prior to constructing the release. 
In most instances, a clearly written release that is easily understandable and thorough will be upheld in court, provided that it does not infringe upon current laws. Many cases have been decided on summary judgment based on the signing of a release by the participant prior to their injury. One of the primary elements of a sound liability release is that it is labeled as such. Many times a plaintiff may argue that they did not know what they were signing. If the reason for this is that the participant neglected to read the document before signing it, this will likely not be an effective argument. However, if the release is not labeled properly or is constructed in such a way that it misleads the participants, the argument may be valid. In the 2004 New York case of Applbaum v. Golden Acres Farm and Ranch (333 F. Supp. 2d 31, 2004) a nine year old girl was seriously injured when she fell from the pony she was riding on a group trail ride. The pony circled and stepped on the child's leg causing a serious fracture. The parents filed suit against the stable, alleging negligence in their failure to provide a safe pony for the child and failure to provide a lead line on the pony, though this was not standard stable practice. The stable requested summary judgment, stating that prior to the ride, the child's parents had signed a liability waiver. Upon inspection of the waiver the court found that the document contained the names of several other people that were on the trail ride and was labeled at the top as "Stable Arrival List". Though the document contained the statement "participants agree to hold the stable harmless from any and all claims which may arise from injury, which might occur from use of said horse and/or equipment ...." (333 F. Supp. 2d 31, 2004), there was a genuine issue of material fact as to whether or not the participants were aware that they were signing a release of liability. Further, the court found that the statement contained in the Arrival List "does not shield Golden Acres from its own negligent conduct". This case was remanded to trial based upon the plaintiff's claim of negligence.

One common and useful practice for requiring participants to sign a release is to request that they initial each paragraph in an effort to show that they read and understood the meaning of the document. This was successfully demonstrated in the 2005 New York case of Eslin v. County of Suffolk(795 N. Y. S. 2d 349, 2005). The plaintiff in this case was injured while participating in a group trail ride at Deep Hollow Ranch when the horse she was riding unexpectedly went into a gallop causing her foot to become 
dislodged from the stirrup resulting in a fall. Prior to the ride, the plaintiff signed a document labeled as a Horse Rental Agreement and Liability Release Form. The plaintiff argued that she was unaware that signing the document would bar her claim in the event of an injury. It was shown that the plaintiff had initialed each paragraph of the document; specifically the paragraph that warned of the risks inherent in horseback riding, including that the horses could stop short or change directions or speed at will. The defendant in this case was granted summary judgment based on the assumption of risk by the plaintiff in knowingly participating in the activity.

One of the most common arguments regarding disclaimers is that the release did not clearly explain the risks associated with horseback riding so that someone with little to no knowledge of horses can clearly understand the potential of horses to cause injury. It is important that the release clearly outline the risks inherent to equestrian activities. Though most people are aware that a horse may buck them off, there are many cases in which persons sustain injury from other behaviors associated with the horse. Aside from bucking, horses may kick, bite, strike, step on, or drag their handlers and riders without warning. They may also kick at other horses or dogs, striking a person in the process. Even the most well trained horse will startle at a sudden unexpected stimulus, and for many inexperienced riders a small reaction from the horse may be enough to dislodge the person from the saddle. Also, many people are not aware that certain things they do while riding can trigger the horse to misbehave. For example, many may be unaware that a normally calm and well behaved horse can often become excited and difficult to handle when separated from other horses, when in the presence of a stallion, or simply by changing the horse's established routine. There are perhaps infinite circumstances in which a person may become injured during equestrian activities. Compound this with the tendency for inexperienced riders to jerk on the reins, scream for help, and squeeze the horse with their legs if they are scared, and there is a large potential for accidents to occur.

When constructing a sound release, it may be impossible to fully explain all of the risks and dangers associated with horseback riding. Some states are more favorable to liability waivers than others and may apply a broader standard to interpreting the waiver. States such as Hawaii and New York tend to view waivers in a light more favorable to 
the plaintiff and interpret disclaimer very literally. For example, in the 2004 Hawaii case of King v. CJM Country Stables(WL 943443, 2004), the court denied summary judgment in a case where a woman was bitten by a horse while on a trail ride. Prior to the ride the plaintiff signed a waiver which described the risks associated with horseback riding in the following terms:

"1. I acknowledge that horseback trailrides entails known and unanticipated risks which could result in physical or emotional injury, ... to myself... I understand that such risks simply cannot be eliminated without jeopardizing the essential qualities of the activity. The risks include, among other things: ...horses, irrespective of their previous behavior and characteristics, may act or react unpredictably based upon instinct, fright, or lack of proper control by rider; latent or apparent defects or conditions in ... animals...; acts of other participants in this activity;... contact with plants or animals;... Furthermore, C.J.M. guides have difficult jobs to perform. They seek safety, but they are not infallible.... They may give inadequate warnings or instructions, and the equipment being used might malfunction.

2. I expressly agree and promise to accept and assume all of the risks existing in this activity. My participation in this activity is purely voluntary, and I elect to participate in spite of the risks.

3. I hereby voluntarily release ... and hold harmless C.J.M. from any and all claims, demands, or causes of action which are in any way connected with my participation in this activity...including any such Claims which allege negligent acts or omissions of C.J.M....

I have had sufficient opportunity to read this entire document, I have read and understood it, and I agree to be bound by its terms" (WL 943443 p.1-4, 2004).

In this case the court ruled that summary judgment was inappropriate. The statement issued by the court was that "there are genuine issues of material fact... as to whether the Release Form constitutes a valid waiver of Defendant's liability and accordingly DENIES Defendant's Motion for Summary Judgment” (WL 943443 p.5, 
2004). The court gave a two-pronged reason for this finding. First was the issue of whether or not the stable was negligent in the biting accident, and second was the issue of whether or not being bitten by a horse was included as one of the inherent risks of horseback riding based upon the wording of the waiver.

In some states the use of particular phrases in the liability release may make the application of the release in court illegal. For example, many states will deem a release illegal if it is worded in such a way as to attempt to release the business from its own negligence. Generally speaking, a release will usually protect the activity sponsor in instances of injury due to the inherent and unavoidable risks associated with participation in the activity. Though this may vary among the states, the majority of releases will not be effective in limiting liability based on obvious negligence, even though this may be explicitly stated in the wording. In some states, such as Montana, the entire contract may be void if it contains such statements. However, this does not necessarily mean that the release will be useless, as it may be possible to present the signed waiver as evidence that the participant was aware of the risks involved. This was evidenced in McDermott v. Carrie, LLC (329 Mont. 295, 2005). In this case a man was injured when his finger was severed while attempting to untie a horse from a fence prior to a group trail ride. The plaintiff had signed a waiver which attempted to release the stable from liability for any and all injuries including those resulting from negligence. Though the court found the application of the release to be illegal based on Montana law, it did allow the defendant to show the signed waiver as proof that the plaintiff was aware that horseback riding was dangerous and that horses have the capacity to cause serious injury. The case was remanded to trial based upon the issue of negligence.

Just as it is important to include a clear description of the types of risks associated with horses, it is also essential to include all parties that are intended to be covered in the release. The waiver should state in very concise terms the parties that are protected from liability by name, not simply 'owner' or 'stable'. Neglecting to do this may result in the stable or horse owner being held liable, even though the participant signed a valid waiver. This occurred in the 1998 Wisconsin case of Park-Childs v. Mrotek's, Inc.(578 N.W. 2d $210,1998)$. Here the plaintiff was injured on a trail ride after signing a waiver. The court 
found that the waiver only mentioned the stable by name in the first sentence of the contract, but did not specifically release the stable from liability, but only referred to the 'owner' in that portion of the document. The waiver was found to be invalid, and the stable was not protected from liability in this case.

In most states a signed liability release form is admissible in court as long as the wording of the release is not in violation of established state laws. In any case, a properly constructed liability release form is a useful tool in creating awareness among participants about the risks involved in the activity, in showing that the riders accepted the risks, and possibly discouraging a law suit or preventing the suit from getting to trial.

\section{Disclaimers and West Virginia Law}

West Virginia is one of eight states that require equine activity sponsors to present a liability waiver to participants prior to allowing the participants to engage in the activity. In these states, having a disclaimer is not only a good idea; it is required in order for the activity sponsor to receive protection under the equine activity statutes. Tourism and recreational opportunities are extremely important to the West Virginia economy. In 2005 the total economic impact of the recreational and leisure industry in West Virginia equaled more than 53 billion dollars. This amount has been steadily increasing since approximately 1990 (Witt, 2007). For this reason much attention has been given to recreational activities with respect to legislation in an effort to encourage recreation based businesses and to provide liability protection for these businesses. In the previously cited West Virginia case of Rutecki v. CSX Hotels, Inc. (S.D. WL 192514, 2007) the plaintiff filed suit after she sustained injury while on a group trail ride at the Greenbriar Resort. The court ruled in favor of CSX Hotels based upon the defendant's presentation of a signed waiver prior to the accident. Interestingly the plaintiff in this case was a practicing attorney. Rutecki attempted to get around her signed waiver by arguing that she only read the third page which required her signature and was unaware that she was signing a waiver of liability. During the hearing Ms. Rutecki's waiver was presented as evidence. Here the third page of the document was clearly labeled as a "Notice, Release and 
Indemnification" (S.D. WL 192514, 2007). The court granted summary judgment to the defendant based largely on the presence of the waiver.

In terms of providing a sound disclaimer that will protect the equine activity sponsor in the event of an accident, it has been stated that a comprehensive description of the risks should be included in the wording of the release. This may be very difficult to construct in states where liability waivers are viewed narrowly by the courts. There have been relatively few cases tried in West Virginia regarding the signing of waivers and injury while participating in equine activities. It is likely that the Rutecki case will serve as a baseline for other cases involving equine accidents and waivers. 


\section{Chapter V}

\section{CONCLUSIONS AND RECOMMENDATIONS}

Upon examining the equine activity statute for West Virginia as compared with the statutes present in other states, one can gather that the West Virginia statute is comparatively less comprehensive than many others. The West Virginia statute appears to have been constructed in order to afford protection to equine businesses such as public riding stables, and to those who organize equestrian events such as horse shows, parades, rodeos, and other forms of competition. The statute protects only those who organize, promote, present or provide equestrian activities, or facilities for the activities, regardless of compensation. It is constructed in such a way that it may be narrowly construed; however it does not specifically protect equine professionals such as veterinarians, or farriers from liability, as many other states do. The activities that are afforded protection under the statute do not make mention of breeding or foaling activities, the loading, unloading, and transporting of horses, or the riding and inspecting of horses belonging to another. These activities are often associated with a greater risk for injury due to factors such as the excitement level of horses during breeding times, the potential for injury while transporting horses, and the increased danger of riding a horse that the participant is unfamiliar with. These are all statements which are included in the majority of the other state statutes. The statute also does not cover any activities associated with track racing; however this is common among most states that provide an equine activity statute.

In order for the West Virginia statute to provide a more effective level of protection for equine professionals and others involved in the equine industry, it would be helpful to include in the list of activities covered those activities that typically contain a higher risk of injury. These may include riding horses belonging to another party for the purpose of a pre-purchase exam, breeding activities, and the transporting of horses. It may also be beneficial to include veterinarians and farriers among the equine professionals afforded protection from liability, assuming no negligence was found.

In terms of the duty of the horseman, the West Virginia statute contains a list of five criteria that the horseman shall meet, however there is no statement regarding whether or not the person is barred from protection of the statute if one or more of the 
criteria are not met. Many other states require that activity sponsors post clearly visible signs where participants are likely to see them. In addition to a signed waiver, the requirement of posted signs in West Virginia stables may help the activity sponsor show that the participant was fully aware of the risks associated with the activity.

It is interesting to note that the West Virginia Code requires that underage participants in other recreational activities such as bicycling and ATV riding must wear helmets (W. Va. Code s 17F-1-8). Failure to do so may result in fines and misdemeanor charges against the parent or guardian of the child. This is not the case when participating in equestrian activities, though some stables may require this on an individual basis. Requiring the use of helmets by children under the age of 16 may not only reduce serious injury to children, but may also help to protect stable owners from liability.

\section{Non-Random Survey Results}

In an effort to gain insight into the knowledge base of horse owners in West Virginia regarding liability laws an informal, non-random survey of 26 members of the equine industry was conducted. Survey participants included many pleasure horse owners, and several farriers, equine veterinarians, and a few horse trainers. The complete questionnaire is attached in Appendix C. When asked whether or not they were concerned with liability issues associated with horse ownership, half of the respondents (13 of 26) replied 'yes'. Most of those that answered yes to this question explained their concern by relating that horses are unpredictable and that chances of injury were relatively high in working around horses. Some also expressed concern that many people that come into contact with their horses are inexperienced and often are not aware of the dangers associated with equestrian activities. Of the participants that responded 'no' to this question (13 of 26), seven individuals were under the impression that a person cannot be sued in West Virginia for horse related accidents because of the liability law.

Under the West Virginia Equine Activity Statute a horseman must have a certain amount of liability insurance in order to be protected from liability in the event of an injury. When survey participants were asked if they possessed insurance that covered equestrian activities three people were unsure, seven people responded 'yes', and 16 replied 'no'. When asked if they had read all or a portion of the WV Equine Activity 
Statute, $30 \%$ ( 8 of 26 ) responded 'yes'. The remainder of participants (18 of 26) had not read the statute with 14 people responding that they were unaware of the existence of the statute. Of those that had previously read the statute, 5 respondents replied that they felt the statute was inadequate in terms of protecting them from liability expressing that there were likely loopholes in the wording that would leave an opening for a successful lawsuit.

Answers varied when participants were asked to name the main issues prohibiting growth of the equine industry in West Virginia. Most responded with comments such as the lack of infrastructure, the fragmented segments of the equine industry which do not work together, the lack of coordinated efforts to assist horse owners, and the unfavorable perceptions of out-of-state residents regarding West Virginia. The majority was unsure as to whether changes in the equine activity statute would serve to encourage growth in the industry or not. Participants were also largely unsure of what changes to the wording of the statute should be made since the majority had not read the statute and those that did read it were unclear as to its exact content.

When asked whether they believed West Virginia should require riders under the age of 16 to wear an approved safety helmet the response was overwhelmingly positive. The majority of participants ( 23 of 26 ) responded 'yes' to this question, many adding that they believed helmets should be required for all ages, not just minors. When asked if WV horse owners would benefit from an educational program regarding the laws and risk management strategies for horse owners, $100 \%$ of participants replied 'yes'. Many suggestions were made as to the content of the educational program but the main concern seemed to be how horse owners might protect themselves from liability and what laws are currently in place to address these issues.

Further research is needed in the area of expanding the educational curriculum at West Virginia University to include liability and negligence concerns for operators of equine businesses and other recreation-based businesses in the state. This curriculum should be made available to horse owners and equine professionals as well as to college students, possibly through the WVU Extension Service. Using the participant comments and information gathered during the completion of this work, a sample equine liability and risk management curriculum for horse owners is included in Appendix D. This 
information could be delivered through a series of lectures at various locations around the state or could be expanded as an online adult education course.

Currently, there are several inconsistencies between the laws regulating equestrian safety as compared to the more comprehensive laws regulating other types of recreation, such as ATV riding, white water rafting, and skiing. Based on the survey results and the research presented, it would be beneficial to examine the possibility of enacting a helmet law for minors involved in equestrian activities in West Virginia. Students entering the field of law should have a clear view of the regulatory environment regarding recreation and tourism in West Virginia, particularly because the state's economy relies heavily on tourism and outdoor industries. 


\section{Appendix A \\ Explanation of Terms}

Assumption of Risk-Implied, stated, or demonstrated willingness of a participant to accept certain dangers that accompany an activity.

Burden of Proof- Responsibility for proving or disproving facts involved in a case.

Contributory Negligence- Any negligent act by a complaining party which contributed to or caused the complaining party's injury.

Defendant-The party against whom the action or suit is brought.

Discipline- The specific activity or sport that the participant is involved in such as dressage, show jumping, barrel racing, etc.

Duty- The obligation of the responsible party to meet legal requirements.

Equine-Family of mammals including horses, mules, and donkeys.

Equine Activity Sponsor- Those that provide facilities and/or management services for equestrian sport.

Farrier- Professional blacksmith or person who trims and/or replaces shoes on an equine. Green broke-Used to describe any equine with limited experience and time under saddle. Inherent Risk-Dangers associated with equine activities which encompass the natural behavior of the horse.

Negligence-Basis for liability in a civil case. Requires duty, act, accident, and injury.

Plaintiff- Complaining party in a lawsuit.

Propensity-Tendency of something to behave in a certain, predictable fashion based upon past behavior.

Release-Contract limiting the person who signs it on their ability to sue.

Statute-Laws created by legislatures.

Strict Liability-Legal liability that exists regardless of negligence.

Tack-Equipment used in the riding, driving, or training or horses. 


\section{Appendix B}

\section{CHAPTER 20. NATURAL RESOURCES.}

\section{ARTICLE 4. EQUESTRIAN ACTIVITIES RESPONSIBILITY ACT.}

\section{\$20-4-1. Legislative purpose.}

The Legislature finds that equestrian activities are engaged in by a large number of citizens of West Virginia and that such activities also attract to West Virginia a large number of nonresidents, significantly contributing to the economy of West Virginia. Since it is recognized that there are inherent risks in equestrian activities which should be understood by participants therein and which are essentially impossible for the operators of equestrian businesses to eliminate, it is the purpose of this article to define those areas of responsibility and those affirmative acts for which the operators of equestrian businesses shall be liable for loss, damage or injury suffered by participants, and to further define those risks which the participants expressly assume and for which there can be no recovery.

\section{\$20-4-2. Definitions.}

In this article, unless a different meaning plainly is required:

(1) "Equestrian activity" means any sporting event or other activity involving a horse or horses, including, but not limited to:

(A) Shows, fairs, competitions, performances or parades;

(B) Any of the equine disciplines such as dressage, hunter and jumper shows, grand prix jumping, three day events, combined training, rodeos, driving, western games and hunting;

(C) Rides, trips or hunts;

(D) Riding classes, therapeutic riding programs, school and college sponsored classes and programs, or other classes in horsemanship;

(E) The boarding or keeping of horses; and

(F) Providing equipment or tack.

(2) "Horseman" or "operator of a horseman's business" means any individual, sole proprietorship, partnership, association, public or private corporation, the United States or any federal agency, this state or any political subdivision of this state, and any other legal entity which engages, with or without compensation, in organizing, promoting, presenting or providing equestrian activities or in providing facilities for equestrian activities. 
(3) "Horse" means each animal of the horse kind, in every class or breed of horses, and, without limitation or exception, all members of the genus Equus and family Equidae.

(4) "Participant" means any person using the services or facilities of a horseman so as to be directly involved in an equestrian activity.

\section{§20-4-3. Duties of horsemen.}

Every horseman shall:

(1) Make reasonable and prudent efforts to determine the ability of a participant to safely engage in the equestrian activity, to determine the ability of the horse to behave safely with the participant, and to determine the ability of the participant to safely manage, care for and control the particular horse involved;

(2) Make known to any participant any dangerous traits or characteristics or any physical impairments or conditions related to a particular horse which is involved in the equestrian activity of which the horseman knows or through the exercise of due diligence could know;

(3) Make known to any participant any dangerous condition as to land or facilities under the lawful possession and control of the horseman of which the horseman knows or through the exercise of due diligence could know, by advising the participant in writing or by conspicuously posting warning signs upon the premises;

(4) In providing equipment or tack to a participant, make reasonable and prudent efforts to inspect such equipment or tack to assure that it is in proper working condition and safe for use in the equestrian activity;

(5) Prepare and present to each participant or prospective participant, for his or her inspection and signature, a statement which clearly and concisely explains the liability limitations, restrictions and responsibilities set forth in this article.

\section{\$20-4-4. Duties of participants.}

It is recognized that equestrian activities are hazardous to participants, regardless of all feasible safety measures which can be taken.

Each participant in an equestrian activity expressly assumes the risk of and legal responsibility for any injury, loss or damage to person or property which results from participation in an equestrian activity. Each participant shall have the sole individual responsibility for knowing the range of his or her own ability to manage, care for, and control a particular horse or perform a particular equestrian activity, and it shall be the duty of each participant to act within the limits of the participant's own ability, to maintain reasonable control of the particular horse or horses at all times while participating in an equestrian activity, to heed all posted warnings, to perform equestrian activities only in an area or in facilities designated by the horseman and to refrain from 
acting in a manner which may cause or contribute to the injury of anyone. If while actually riding in an equestrian event, any participant collides with any object or person, except an obviously intoxicated person of whom the horseman is aware, or if the participant falls from the horse or from a horse-drawn conveyance, the responsibility for such collision or fall shall be solely that of the participant or participants involved and not that of the horseman.

A participant involved in an accident shall not depart from the area or facility where the equestrian activity took place without leaving personal identification, including name and address, or without notifying the proper authorities, or without obtaining assistance when that person knows or reasonably should know that any other person involved in the accident is in need of medical or other assistance.

\section{\$20-4-5. Liability of horsemen.}

(a) A horseman shall be liable for injury, loss or damage caused by failure to follow the duties set forth in section three of this article where the violation of duty is causally related to the injury, loss or damage suffered. A horseman shall not be liable for any injury, loss or damage caused by the negligence of any person who is not an agent or employee of such horseman.

(b) A horseman shall be liable for acts or omissions which constitute gross negligence or willful and wanton conduct which is the proximate cause of injury to a participant.

(c) A horseman shall be liable for an intentional injury which he or she inflicts upon a participant.

(d) Every horseman shall carry public liability insurance in limits of no less than one hundred thousand dollars per person, three hundred thousand dollars per occurrence and ten thousand dollars for property damage.

\section{\$20-4-6. Liability of participants.}

Any participant shall be liable for injury, loss or damage resulting from violations of the duties set forth in section four of this article.

\section{\$20-4-7. Applicability of article.}

The provisions of this article do not apply to the horse racing industry that is regulated by the provisions of article twenty-three, chapter nineteen of this code. 


\section{Appendix C}

\section{WV Horse Owner Survey}

September 18, 2008

Dear Equine Owner:

We are conducting a study of equine liability laws and issues in West Virginia. In particular we are concerned with the adequacy of the WV Equine Activity Statute. Your input into the study is sought to measure the knowledge, need, and issues associated with WV Equine Liability Laws. Please answer the following ten questions and return the survey. Thank you for your time and efforts.

Sincerely,

Jennifer Poling

c/o Dennis K. Smith

Davis College of Agriculture, Forestry and Consumer Sciences

West Virginia University

PO Box 6108

Morgantown, WV 26506-6108

1. Are you concerned with the liability issues associated with horse ownership in the case of an injury to someone? Yes No Explain why

2. Do you currently have a personal liability insurance policy that will cover equestrian activities? Yes No

3. Have you read all or a portion of the current WV Equine Activity Statute, WV Stat. 20-4-1, which provides liability protection for horse owners involved in certain types of equestrian activities? Yes__ No _ If no explain

4. Do you believe the current WV Equine Activity Statute is adequate in providing liability protection for WV horse owners and equine professionals? Yes No If no explain

5. Do you believe that changes to the statute could encourage more activity in the equine industry in WV? Yes No If yes explain 
6. In your opinion what are the main issues prohibiting growth of the equine industry in West Virginia?

7. How would you suggest changing the WV Equine Activity Statute to make it more effective in protecting horse owners and equine professionals from liability?

8. Do you believe WV should require all riders under the age of 16 to wear an approved safety helmet? Yes

No ___ Why

9. Do you feel that WV horse owners and equine professionals would benefit from an educational program regarding current laws and risk management strategies associated with equine activities? Yes No

10. What are your suggestions for the content and delivery of such a program? 


\section{Appendix D}

Course Content: Equine Liability and Risk Management for WV Horse Owners

Introduction to Law

Liability

Negligence

System Structure

WV Equine Activity Statute

Definitions

Persons Covered

Activities Covered

Requirements of Participants and Horsemen

Dangerous Propensities and Duty to Warn

Supplemental Laws

Recreational Use Statute

Landowner Liability

Animal Abuse

Livestock and Fencing Laws

Trespassing Laws

Risk Management Strategies

Safety and Your Facility

Signage Requirements

Construction of a Sound Waiver

Liability Insurance 


\section{References}

Alabama State Senate. Alabama Equine Activity Statute. S 6-5-337. State of Alabama, 1994. Arizona State Senate. Courts and Civil Proceedings Chapter 5. Limitations of Actions Article 3. Personal Actions. A.R.S. s 12-553. State of Arizona, 1994.

Beethe, Michael, Esq. Equine Liability Statutes: What Do They Protect? July 1998. 19 Oct: 2006 http://www.equispec.com/archive/df02.phtml

Clark-Dawe, James, Esq. Equine Liability: What Every Horse Owner Needs to Know. Middleton: Carriage House Publishing, 2003.

Clarkson, K.W., R.L. Miller, and G.A. Jentz. West's Business Law. St. Paul: West Publishing Company, 1983.

Cripps, R.A. "Horse Related Injury in Australia.” Australian Injury Prevention Bulletin 24, Alttw Cat.No. INJ26, May 2000. Research Center for Injury Studies, Flinders University, 2000.

Dawson, Robert. Dangerous Propensities and Your Legal Liability. 24 Oct: 2006. http://utopia.utexas.edu/explore/equine/horselaw/danger.htm

Hughes, D.W., J.M. Woloshuk, A.C. Hanham, D.J. Workman, D.W. Snively, and P.E. Lewis. West Virginia Equine Economic Impact Study. West Virginia University, 2005.

Illinois State Senate. Illinois Equine Activity Statute. 745 ILCS 47. State of Illinois, 1995.

Kaplan, H. and J. Kuckelman. The International Comparative Legal Guide to: Product Liability 2006. Global Legal Group, 2006.

Michigan State Senate. Michigan Equine Activity Statute. House Bill 5006. State of Michigan, 1994. 
Mullens, H.B., Esq. Personal Interview. 10 May 2008.

National Economic Impact of the U.S. Horse Industry. 2005. American Horse Council. 19

Oct: 2006 http://www.horsecouncil.org/statistics.htm.

New Hampshire State Senate. Running at Large. NH ST 467:1. State of New Hampshire, 1973.

New Jersey State Senate. Amusements- Equestrian Activities- Liability. NJ ST 5:15-1. State of New Jersey, 1998.

New York State Senate. New York Equestrian Helmet Statute. S 1265. State of New York, 1999.

Oklahoma State Senate. Oklahoma Livestock Activities Liability Limitation Act. Chapter 326 H.B. No. 1152. State of Oklahoma, 1999.

The Horse Shelter. Adoption Contract Page. 2005 http://www.thehorseshelter.org/adopt.htm.

Thomas, K.E., J.L. Annest, J. Gilchrist, and D.M. Bixby-Hammet. Nonfatal Horse Related Injuries Treated in Emergency Departments in the United States 2001-2003. National Center for Injury Prevention, 2006.

Uchtmann, Donald, J.W. Looney, N.G.P. Krausz, and H.W. Hannah. Agricultural Law Principles and Cases. New York: McGraw-Hill, Inc., 1981.

Waller, A.E., J.L. Daniels, N.L. Weaver, and P. Robinson. “Jockey Injuries in the United States." JAMA 283.10 (2000): 1326-8.

West Virginia State Senate. WV Code: Cruelty to Animals Statute. S 61-8-19. State of West Virginia, 2000.

West Virginia State Senate. WV Code: Equestrian Activities Responsibility Act. S 20-4. State of West Virginia, 1994. 
West Virginia State Senate. WV Code: Helmet Law. S 17F-1-8. State of West Virginia.

West Virginia State Senate. WV Code: Humane Officers Statute. S 7-10-1. State of West Virginia, 1990.

West Virginia State Senate. WV Code: Unlawful Running at Large. S 19-18-3. State of West Virginia.

West Virginia State Senate. WV Code: West Virginia Recreational Use Statute. S 19-25-1. State of West Virginia, 1997.

Witt, T. and J.S. Leguizamon. Tourism and the West Virginia Economy. West Virginia Univeristy, 2007.

Wisconsin State Senate. Miscellaneous General Provisions. Chapter 895. 525. State of Wisconsin, 1994.

Wyoming State Senate. Recreation Safety Act. S 1-1-121. State of Wyoming, 1996.

\section{Cases}

Alaimo v. Racetrack at Evangeline Downs. Louisiana Court of Appeals, WL $2338063^{\text {rd }}$. Cir. (2005).

Allison v. Johnson. Ohio Court of Appeals, WL 589384 (2001).

Amburdey v. Sauder. Michigan Court of Appeals, 238 Mich.App.228,605NW 2d84 (1999)

Applbaum v. Golden Acres Farm and Ranch. New York District Court. 333F. Supp. 2 d31. (2004).

Baker v. McIntosh. Kentucky District Court. 132 s.w.3d 230 (2004).

Balen v. Peltier. Minnesota Appellate Court. WL 163518 (2006).

Browning v. State. Indiana Court of Appeals, WL 1805918 (2007). 
Burns v. Leap. Court of Appeals of Georgia. 645 S.E. 2d 751 (2007).

Carl v. Resnick. Illinois First District Court. 714 N.E. 2d 1 (1999).

Clyncke v. Waneka. Supreme Court of Colorado. WL 570412 (2007).

Cole v. Ladbroke Racing. Michigan Court of Appeals. 241 N.W.2d 169 (2000).

Deans v. Nebraska. Nebraska Appellate Court. Unpublished (1996).

Dodge v. Durdin. Court of Appeals of Texas, WL 3214618 (2005).

Ellertson v. Dansie. Utah District Court. 576 P.2d 876 (1978).

Eslin v. County of Suffolk. Supreme Court of New York. 795 N.Y.S. 2 d349 (2005).

Gibson v. Donahue. Ohio Court of Appeals. 722 N.E. 2d 646 (2002).

Hubbard v. Howard. US District Court of Idaho. 758 F. Supp. 594 (1990).

Hussey v. Seawell. North Carolina Court of Appeals. 527 s.e.2d 90 (2000).

Jividen v. Law v. Kovacs. West Virginia Supreme Court of Appeals. 90-C-162 and 90-C-390 (1995).

Kangas v. Perry. Wisconsin District Court, N.W. 2d 429 (2000).

King v. CJM Country Stables. US District Court of Hawaii, WL 943443 (2004).

Kinley v. Bierly. Pennsylvania Supreme Court, WL 1027901 (2005).

Konan v. George. Massachusetts Supreme Court. WL 1020734 (2002).

Larson-Murphy v. Steiner. Montana Supreme Court. 15 p.3d 1205 (2000).

Lindsay v. Cave Creek Outfitters. Arizona Court of Appeals. 88 P.3d 557 (2003).

McDermott v. Carrie, LLC. Supreme Court of Montana, 329 Mont. 295 (2005).

McGraw v. R and R Investments. Florida Court of Appeals. 877 s0.2d 886 (2004).

Meyer v. Naperville Manner. Illinois Appellate Court. 262 3d. 141 (1994).

Nickell v. Summer. Oklahoma Supreme Court. 943 P. 2d 625 (1997). 
Park-Childs v. Mrotek's, LLC. Wisconsin Appellate Court, 578 N.W. 2d 210 (1998).

Reed v. Clark. South Carolina Supreme Court. 286 s.e. 2d 384 (1982).

Rutecki v. CSX Hotels, Inc. US District Court of West Virginia, S.D. WL 192514 (2007).

Southall v. Gabell. Ohio Municipal Court. 293 N.E. 2d 891 (1972).

Stoffels v. Harmony Hill Farm. Superior Court of New Jersey, Appellate Div. WL 3699549 (2006).

Terrill v. Stacy. Michigan Court of Appeals. WL 473799 (2006).

Wardrop v. Koerner. New York Court of Appeals. 617 N.Y.S. 2d 964 (1994).

Watkins v. County of Prentiss, Mississippi. Supreme Court of Mississippi, 808 So. 2d 971 (2002). 